\title{
Small-scale analysis to rank municipalities requiring slow-moving landslide risk mitigation measures: the case study of the Calabria region (southern Italy)
}

\author{
Giovanni Gullà', Gianfranco Nicodemo², Settimio Ferlisi² $2^{*}$, Luigi Borrelli and Dario Peduto²
}

\begin{abstract}
This paper proposes a three-phase method that combines multi-source (i.e. topographic, thematic, monitoring) input data in a GIS environment to rank —at small $(1: 250,000)$ scale_-administrative units (e.g. municipalities) based on their exposure to slow-moving landslide risk within a selected area (e.g. a region) and, accordingly, detect those primarily requiring mitigation measures. The method is applied in the Calabria region (southern Italy) where several municipalities are widely affected by slow-moving landslides that systematically cause damage to buildings and infrastructure networks resulting in significant economic losses. The results obtained are validated based on the information gathered from previous studies carried out at large (municipal) scale. The work undertaken represents a first, fundamental step of a wider circular approach that can profitably facilitate the decision makers in addressing the issue of the slowmoving landslide risk mitigation in a sustainable way.
\end{abstract}

Keywords: Slow-moving landslides, Urban areas, Remote sensing, GIS, Small-scale

\section{Introduction}

Slow-moving landslides (SMLs) are slope instabilities with existing (buried) slip zones where the materials are predominately fine-grained with a visco-plastic behaviour (Bertini et al. 1984; Borrelli and Gullà 2017; Di Maio et al. 2013; Ferlisi 2004; Fernández-Merodo et al. 2014; Grana and Tommasi 2014; Gullà 2014; Leroueil 2001; Picarelli et al. 2004). Owing to their particular kinematic features, associated with a permanent or episodic activity, these landslides mainly cause direct damages to exposed buildings and/or infrastructure networks the severity of which progressively increases over time (Antronico et al. 2015; Ferlisi et al. 2021; Peduto et al. 2017). Consequently, also the SML-induced risk increases with

\footnotetext{
*Correspondence: sferlisi@unisa.it

${ }^{2}$ Department of Civil Engineering, University of Salerno, via Giovanni

Paolo II, 132, 84084 Fisciano, Salerno, Italy

Full list of author information is available at the end of the article
}

detrimental effects on the abovementioned exposed elements that are expected to be higher as displaced masses experience sudden accelerations due to rainfall or earthquakes (Donnini et al. 2017; Gullà 2014; Mavrouli et al. 2019; Negulescu et al. 2014; Uzielli et al. 2015).

To address this issue, which is of particular concern for central and local authorities in charge of SML risk management, top-down multi-scale methodological approaches (Cascini 2015) may help in: prioritizing (at small scale) the municipalities-within a regionwhose SML-affected urban areas require risk mitigation measures; planning (at medium scale) well-defined categories of risk mitigation measures (e.g. slope stabilization works) in the urban area of a municipality selected among the most exposed ones to SML risk based on the outcomes of small-scale analysis; scheduling (at large scale) the implementation, with a proper allocation of economic resources, of the most suitable structural/nonstructural interventions among the categories planned at 
medium scale; designing (at detailed scale) the interventions selected at large scale (Ferlisi et al. 2019).

Focusing on the analysis at small scale (Fell et al. 2008), related activities have to be carried out by using basic methods that involve-as input data to be managed in a GIS environment-topographic and thematic (i.e. geolithological, SML inventory, and built-up area) maps as well as monitoring information such as that gathered from conventional or innovative remote sensing techniques (Corominas et al. 2014; Fell et al. 2008). Among the latter, the differential interferometric processing of synthetic aperture radar images (DInSAR) was successfully tested in the last few decades on several case studies involving SMLs (Catani et al. 2005; Noviello et al. 2020; Peduto et al. 2017, 2019b; Wasowski and Bovenga 2014). In particular, DInSAR data proved to be of value and both complementary and supplementary to the conventional geotechnical monitoring (Gullà et al. 2017; Morelli et al. 2020; Peduto et al. 2021b, c; Refice et al. 2019) providing useful information on both the identification of new SMLs boundaries (Herrera et al 2013; Peduto et al. 2016; Wasowski 2006) and the updating of their state of activity (Cascini et al. 2013; Cigna et al 2013) as well as in the analysis of past landslide evidences and in creating and updating, at small and medium scales, inventory maps in specific periods (Raspini et al. 2019; Solari et al. 2019).

Following this line of thought, this paper proposes a method that allows ranking administrative units (e.g. municipalities) exposed to SML risk within a selected area (e.g. a region) and detecting those primarily requiring mitigation measures. The applicability of the proposed method at small scale (i.e. 1:250,000 according to Fell et al. 2008) is tested with reference to the Calabria region (southern Italy) where several municipalities are widely affected by SMLs.

\section{Method and materials}

The proposed method is synthesized in Fig. 1.

In the first phase an operative grid (Fig. 1) - whose geometrical size must be defined according to the spatial resolution of available materials (Fig. 1) -is set (Calvello et al. 2013; Gullà et al. 2008) and the Terrain Computational Units (TCUs) are overlaid on the study area map (Fig. 2a) according to Calvello et al. (2013, 2017). Then, starting from the available materials-geological map, digital terrain model (DTM), built-up urban area map, landslide inventory map, DInSAR data (Fig. 1)-each TCU (Fig. 2a) is associated with the pertaining information (input data) including:

(i) the Lithological Units (LUs), namely groups of lithotypes with a mechanical behaviour that can be assumed as homogeneous at the scale of analysis (i.e. small scale);

(ii) the Slope angle (S), as retrieved from the DTM;

(iii) the presence/absence of an Urban Area (UA), as resulting from the built-up area map;

(iv) the presence/absence of a SML, based on the landslide inventory map;

(v) the DInSAR-derived velocity, computed by averaging the velocity values pertaining to the coherent pixels - if any-within the TCU perimeter (Cascini et al. 2013).

The second phase (Fig. 1) of the method is comprised of two steps.

In the first step, the information assigned to the TCUs is preliminarily associated with the so-called Vulnerable Areas (VAs) which correspond to the portions of the UA affected by SMLs (Fig. 2b). Then, qualitative indicators (Very Low-VL, Low-L, Medium $-\mathrm{M}$ and High $-\mathrm{H}$ ) are assigned to the VAs according to the SML-induced damage severity level expected to the built-up environment owing to LU or S, in turn assessed at both local (l) (i.e. referred to a given VA) and global (g) (referred to the whole SML affecting the same VA) levels. Each of these levels is grouped in four classes. The latter are distinguished in:

(i) LUi $(i=1, \ldots, 4)$ for LUs, considering the LU prevailing in a given VA or in the SML affecting the same VA;

(ii) $\mathrm{Si}(\mathrm{i}=1, \ldots, 4)$ for $\mathrm{S}$, considering the average value of $S$ pertaining to a given VA or to the SML affecting the same VA.

To assign the qualitative indicators to the VAs, two matrices (Lithological consistency matrix in Fig. 3a and Slope consistency matrix in Fig. 3b) are introduced to crosscheck the information associated with the TCUs covering a given VA or the SML affecting the same VA. In particular, the prevailing $L U$ and the average value of $\mathrm{S}-$ referred to one of the considered $\mathrm{LUi} / \mathrm{Si} \quad(\mathrm{i}=1$, ..., 4) classes and based on the information previously associated with the TCUs-are preliminarily assigned to either the VAs (at local level) or the SMLs interacting with the VAs (at global level). The retrieved data are used as input in the above mentioned Lithological consistency (Fig. 3a) and Slope consistency (Fig. 3b) matrices that are applied to each VA and provide as output, for both LU and S, the $\mathrm{VL}_{\mathrm{LU}-1 / \mathrm{g}}, \mathrm{L}_{\mathrm{LU}-1 / \mathrm{g}}, \mathrm{M}_{\mathrm{LU}-1 / \mathrm{g}}, \mathrm{H}_{\mathrm{LU}-1 / \mathrm{g}}$ (see Fig. 3a), and $\mathrm{VL}_{S-1 / \mathrm{g}}, \mathrm{L}_{\mathrm{S}-1 / \mathrm{g}}, \mathrm{M}_{\mathrm{S}-1 / \mathrm{g}}, \mathrm{H}_{\mathrm{S}-1 / \mathrm{g}}$ (see Fig. 3b) qualitative indicators with $\mathrm{l} / \mathrm{g}$ standing for local/global. In particular, the very low (VL) category is assigned if local (l) and global (g) indicators-related to the considered (LU or S) thematic variable-are both ranked 


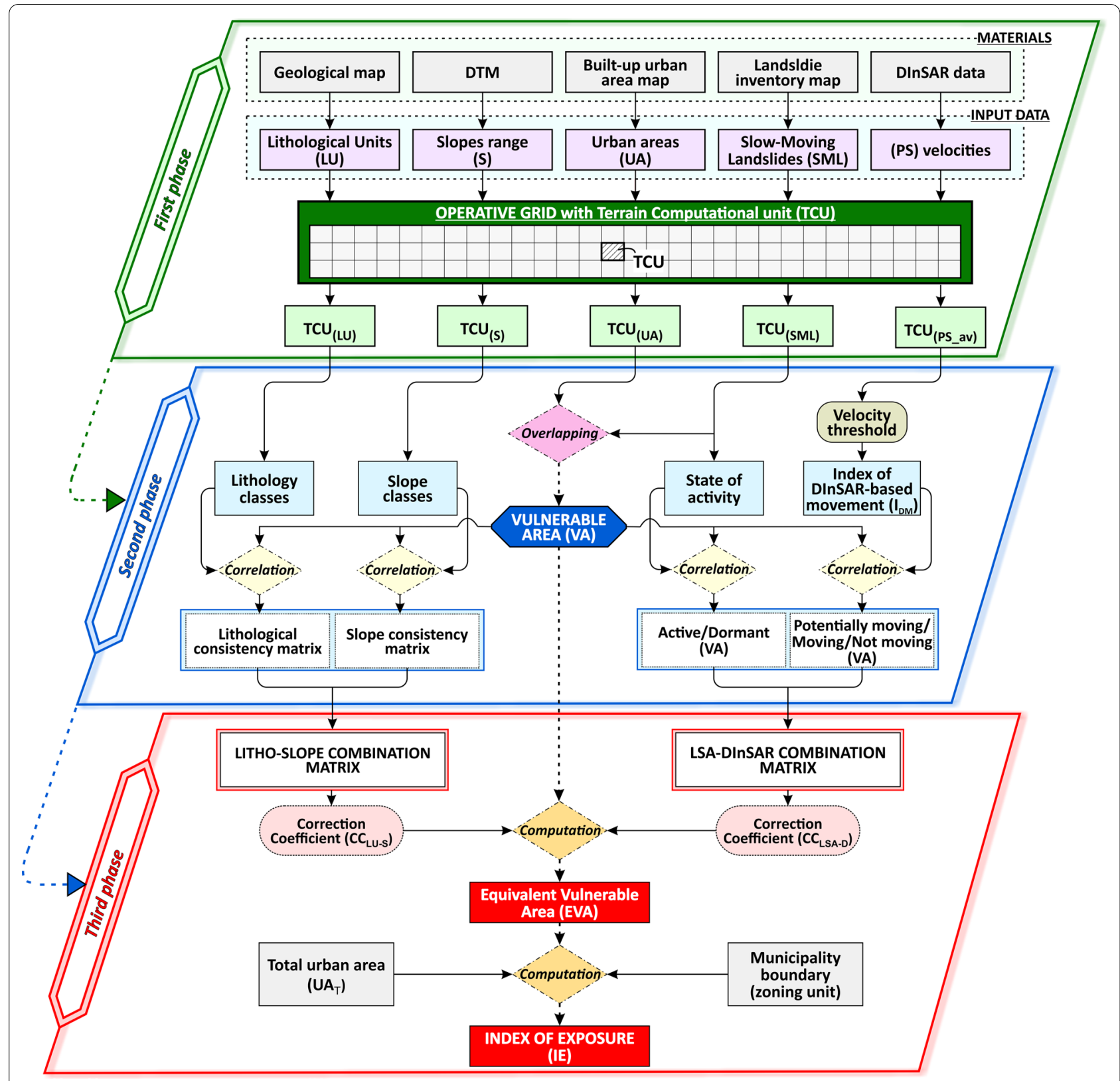

Fig. 1 Flowchart of the proposed method to rank zoning units exposed to slow-moving landslide (SML) risk at small scale

with very low classes; low (L) category, if the highest value of one of the two (local or global) indicators is at most medium and the lowest is at least very low; medium (M) category, if the highest value of one of the two (local or global) indicators is at most high and the lowest value is at least very low or if the highest value of one of the two (local or global) indicators is at most medium and the lowest value is at least low; high $(\mathrm{H})$ category, if the highest value of one of the two (local or global) indicators is high and the lowest value is at least medium.

In the second step, the state of activity of a given SMLi.e. active or dormant (Cruden and Varnes 1996) - and the DInSAR-based condition of movement of the TCUs covering the affected VA are associated with the same VA (Fig. 1). In particular, the former information is directly provided by the landslide inventory map; accordingly, the VA is differentiated into "active" (VA_A) or "dormant" (VA_D) based on the state of activity of the affecting SML 

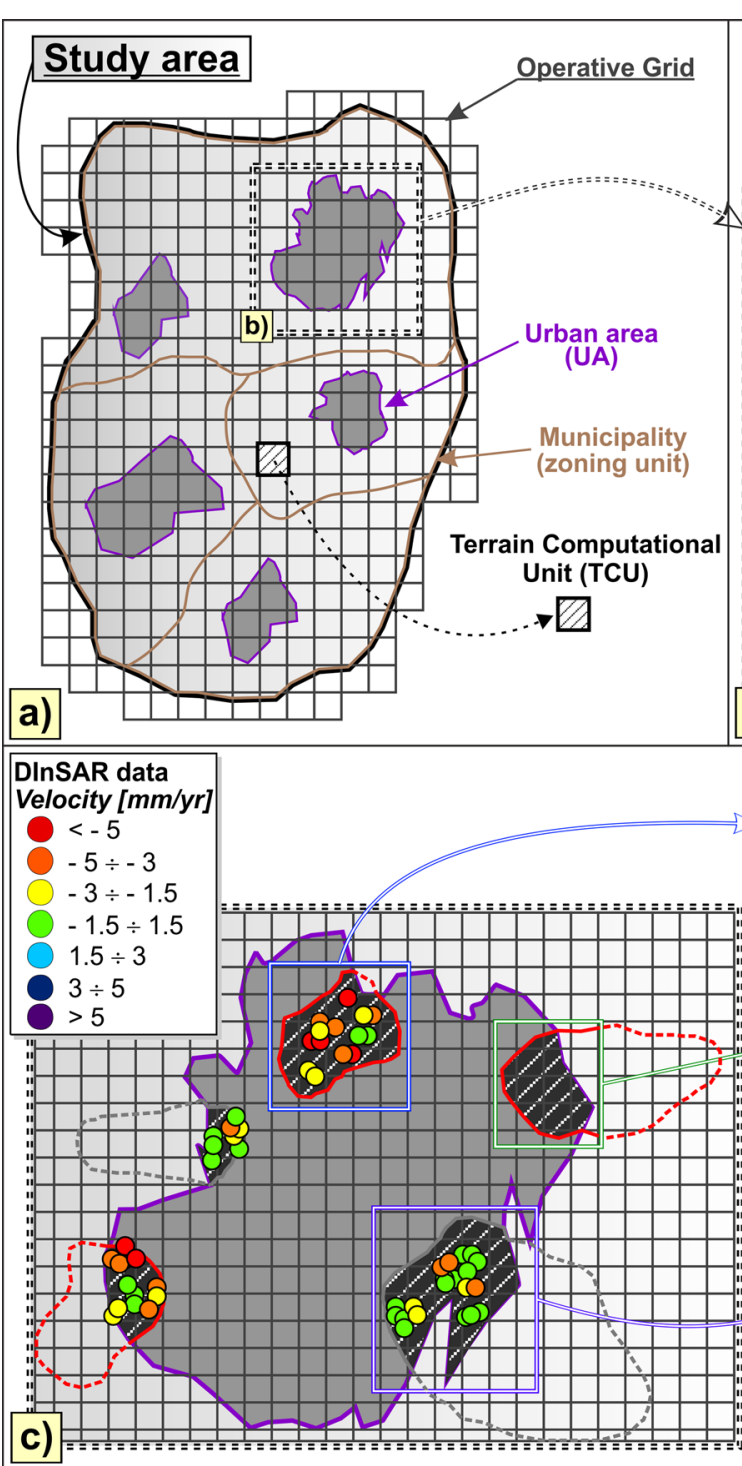

b)
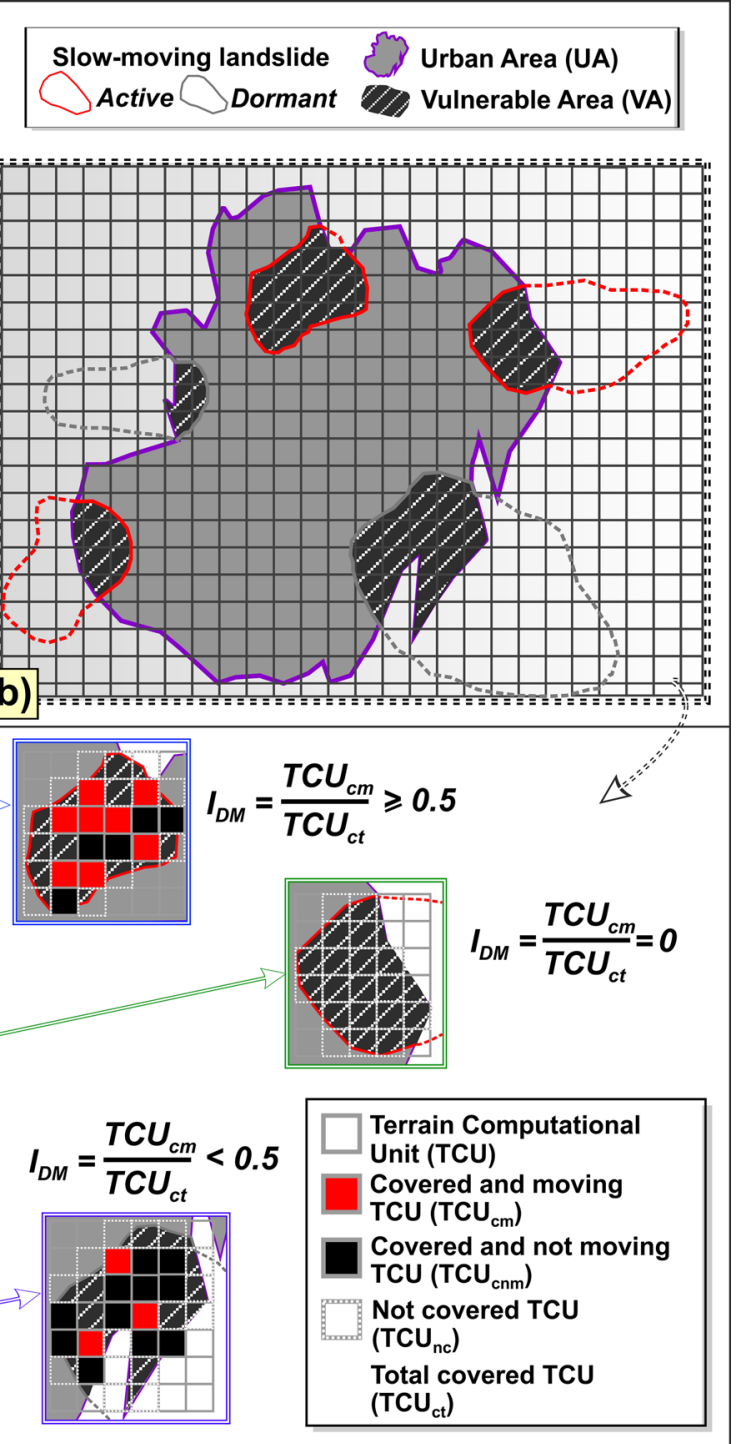

Fig. 2 a Sketch of an operative grid composed by Terrain Computational Units (TCUs) to be defined over the study area and zoning units; $\mathbf{b}$ an example of Vulnerable Area (VA) deriving from the intersection of the built-up urban area with the slow-moving landslides (SMLs); c calculation of the Index of DInSAR-based movement $\left(\mathrm{I}_{\mathrm{DM}}\right)$

(by the way, built-up areas not affected by SMLs were considered as stable or without vulnerable areas, SA). The latter information derives from the preliminary comparison of the average annual velocity values pertaining to the coherent pixels within each TCU covering the VA with a fixed velocity threshold accounting for the precision of DInSAR data, thus allowing the identification of "moving" TCUs. It is worth observing that the two mentioned sources of information are not expected to provide straightforwardly the same indication. Indeed, the state of activity pertains to the whole SML body and is assigned according to movements recorded in the last cycle of seasons (Cruden and Varnes 1996), in relation to the date in which the inventory map was drawn-up. On the other hand, the DInSAR-based displacements are measured on the VA (which is in a specific portion of the SML body that might not reflect the overall kinematics of the entire SML body) in a certain period, namely the one for which synthetic aperture radar images are available. From the perspective of the proposed methodology, merging both sources of information has a two-fold objective: overcoming the qualitative information that is typically associated with the definition of the state of activity of a SML and confirming that the DInSAR-based 


\begin{tabular}{|c|c|c|c|c|c|}
\hline \multirow{2}{*}{\multicolumn{2}{|c|}{$\begin{array}{l}\text { a) Lithological } \\
\text { consistency matrix }\end{array}$}} & \multicolumn{4}{|c|}{ Lithological class (global effect - g) } \\
\hline & & LU1 ${ }_{g}$ & LU2 $_{g}$ & LU3 $_{g}$ & LU4 $_{g}$ \\
\hline \multirow{4}{*}{ 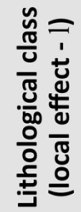 } & LU1 & $\mathrm{VL}_{\mathrm{LU}-\mathrm{H} \mathrm{g}}$ & $\mathrm{L}_{\mathrm{LU}-1 / \mathrm{g}}$ & $\mathrm{L}_{\mathrm{LU}-1 / \mathrm{g}}$ & $\mathrm{M}_{\mathrm{LU}-1 / \mathrm{g}}$ \\
\hline & LU2 & $\mathrm{L}_{\mathrm{LU}-1 / \mathrm{g}}$ & $\mathrm{L}_{\mathrm{LU}-1 / \mathrm{g}}$ & $\mathrm{M}_{\mathrm{LU}-\mathrm{I} / \mathrm{g}}$ & $\mathrm{M}_{\mathrm{LU}-\mathrm{I} / \mathrm{g}}$ \\
\hline & LU3 $_{1}$ & $\mathrm{~L}_{\mathrm{LU}-1 / \mathrm{g}}$ & $\mathrm{M}_{\mathrm{LU}-\mathrm{lg} \mathrm{g}}$ & $\mathrm{M}_{\mathrm{LU}-1 / \mathrm{g}}$ & $\mathrm{H}$ \\
\hline & Lu4 $_{1}$ & $M_{\mathrm{LU}-1 / \mathrm{g}}$ & $\mathrm{M}_{\mathrm{LU}-\mathrm{I} / \mathrm{g}}$ & $H_{L}$ & $\mathrm{H}$ \\
\hline
\end{tabular}

\begin{tabular}{|c|c|c|c|c|c|}
\hline \multirow{2}{*}{\multicolumn{2}{|c|}{$\begin{array}{l}\text { b) } \\
\text { Slope consistency } \\
\text { matrix }\end{array}$}} & \multicolumn{4}{|c|}{ Slope class (global effect - g) } \\
\hline & & S1 $1_{g}$ & $\mathbf{S} \mathbf{2}_{\mathrm{g}}$ & $\mathrm{S3}_{\mathrm{g}}$ & $\mathrm{S} \mathbf{g}_{\mathrm{g}}$ \\
\hline \multirow{4}{*}{ 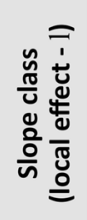 } & $S 1_{1}$ & $\mathrm{VL}_{\mathrm{S}-1 / \mathrm{g}}$ & $\mathrm{L}_{\mathrm{S}-1 / \mathrm{g}}$ & $\mathrm{L}_{\mathrm{S}-1 / \mathrm{g}}$ & $\mathrm{M}_{\mathrm{S}-1 / \mathrm{g}}$ \\
\hline & $\mathbf{S 2}$ & $\mathrm{L}_{\mathrm{S}-1 / \mathrm{g}}$ & $\mathrm{L}_{\mathrm{S}-1 / \mathrm{g}}$ & $M_{S-1 / g}$ & $\mathrm{M}_{\mathrm{S}-1 / \mathrm{g}}$ \\
\hline & S3 & $\mathrm{L}_{\mathrm{S}-1 / \mathrm{g}}$ & $\mathrm{M}_{\mathrm{S}-1 / \mathrm{g}}$ & $\mathrm{M}_{\mathrm{S}-1 / \mathrm{g}}$ & $\mathrm{H}_{\mathrm{S}}$ \\
\hline & S4 & $M_{S-1 / g}$ & $M_{S-1 / g}$ & $H_{S-1 / g}$ & $\mathrm{H}_{\mathrm{S}-1}$ \\
\hline
\end{tabular}
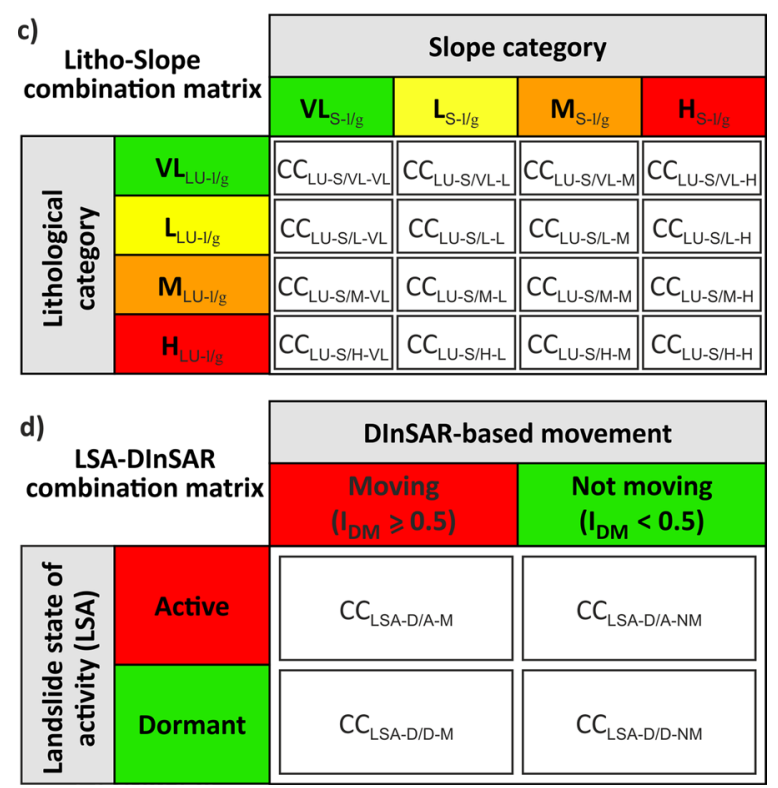

Fig. 3 Matrices used in the second- and third-phase of analysis to evaluate the Equivalent Vulnerable Area (EVA): a Lithological consistency matrix with the considered qualitative indicators $\left(V L_{L U}=\right.$ Very low; $L_{L U}=$ low; $M_{L U}=$ Medium; $H_{L U}=$ High); b Slope consistency matrix with the considered qualitative indicators $\left(\mathrm{VL}_{\mathrm{S}}=\right.$ Very low; $\mathrm{L}_{\mathrm{S}}=$ low; $\mathrm{M}_{\mathrm{S}}=$ Medium; $\mathrm{H}_{\mathrm{S}}=$ High $) ; \mathbf{c}$ Litho-Slope combination matrix with Litho-Slope Correction Coefficients $\left(\mathrm{CC}_{\mathrm{LU}-\mathrm{S}}\right)$; d $L S A$-DInSAR combination matrix with the LSA-DInSAR Correction Coefficients $\left(C C_{L S A-D}\right)$

displacements on the VA are induced by the SML movements.
Then, an Index of DInSAR-based movement $\left(\mathrm{I}_{\mathrm{DM}}\right)$ is introduced (adapted from Peduto et al. 2015; Calvello et al. 2017) (Fig. 2c):

$$
\mathrm{I}_{\mathrm{DM}_{i}}=\frac{\left(\mathrm{TCU}_{\mathrm{cm}}\right)_{i}}{\left(\mathrm{TCU}_{\mathrm{ct}}\right)_{i}}
$$

where $\left(\mathrm{TCU}_{\mathrm{cm}}\right)_{i}$ is the number of moving DInSAR-covered TCUs within the $i$-th VA and $\left(\mathrm{TCU}_{\mathrm{ct}}\right)_{i}$ their total number. Accordingly, the VA is conservatively assumed as (Fig. 2c):

(i) "potentially moving" if the TCUs pertaining to the VA are not covered by DInSAR data;

(ii) "moving" if the $\mathrm{I}_{\mathrm{DM}}$ value equals or exceeds 0.5 (at least the $50 \%$ of the DInSAR-covered TCUs within the $i$-th VA are moving);

(iii) "not moving" if the computed $\mathrm{I}_{\mathrm{DM}}$ is lower than 0.5 (more than $50 \%$ of the DInSAR-covered TCUs within the $i$-th VA are not moving).

In the third phase (Fig. 1), the results obtained in the second phase are used for computing an Index of Exposure (IE) referred to the municipal area that is assumed as zoning unit (Calvello et al. 2013) (Fig. 2a). To this aim, the results of the Lithological consistency and Slope consistency matrices are combined into the Litho-Slope combination matrix (Fig. 3c). The latter allows quantifying the high/low proneness associated with the two thematic categories (LU and S) to induce joint effects (in terms of expected consequences) on the urban area through the introduction of the Litho-Slope Correction Coefficients $\left(\mathrm{CC}_{\mathrm{LU}-\mathrm{S}}\right)$ whose values range from 0 (i.e. null effect) to 1 (i.e. maximum effect).

On the other hand, the information related to the landslide state of activity (LSA) and the DInSAR-based movement of the VAs is combined within a LSA-DIn$S A R$ combination matrix (Fig. $3 \mathrm{~d}$ ). The latter aims to crosscheck these two different sources of information on the status of VA movement-as factor concurring to the severity of expected SML-induced consequences on the UA-through the introduction of a LSA-DInSAR Correction Coefficient $\left(\mathrm{CC}_{\mathrm{LSA}-\mathrm{D}}\right)$ whose values may range from 0 (i.e., null effect) to 1 (i.e., maximum effect). For each VA, the application of the two defined correction coefficients $\left(\mathrm{CC}_{\mathrm{LU}-\mathrm{S}}\right.$ and $\left.\mathrm{CC}_{\mathrm{LSA}-\mathrm{D}}\right)$ allows obtaining an Equivalent Vulnerable Area (EVA) (in $\mathrm{m}^{2}$ ) defined as:

$$
\mathrm{EVA}=\mathrm{VA} \times \mathrm{CC}_{\mathrm{LU}-\mathrm{S}} \times \mathrm{CC}_{\mathrm{LSA}-\mathrm{D}}
$$

Obviously, EVA will be equal to VA if both correction coefficients $\left(\mathrm{CC}_{\mathrm{LU}-\mathrm{S}}\right.$ and $\left.\mathrm{CC}_{\mathrm{L}-\mathrm{D}}\right)$ are unitary in value (i.e. the involved factors can induce a maximum effect in terms of expected consequences to the VA). Otherwise, 


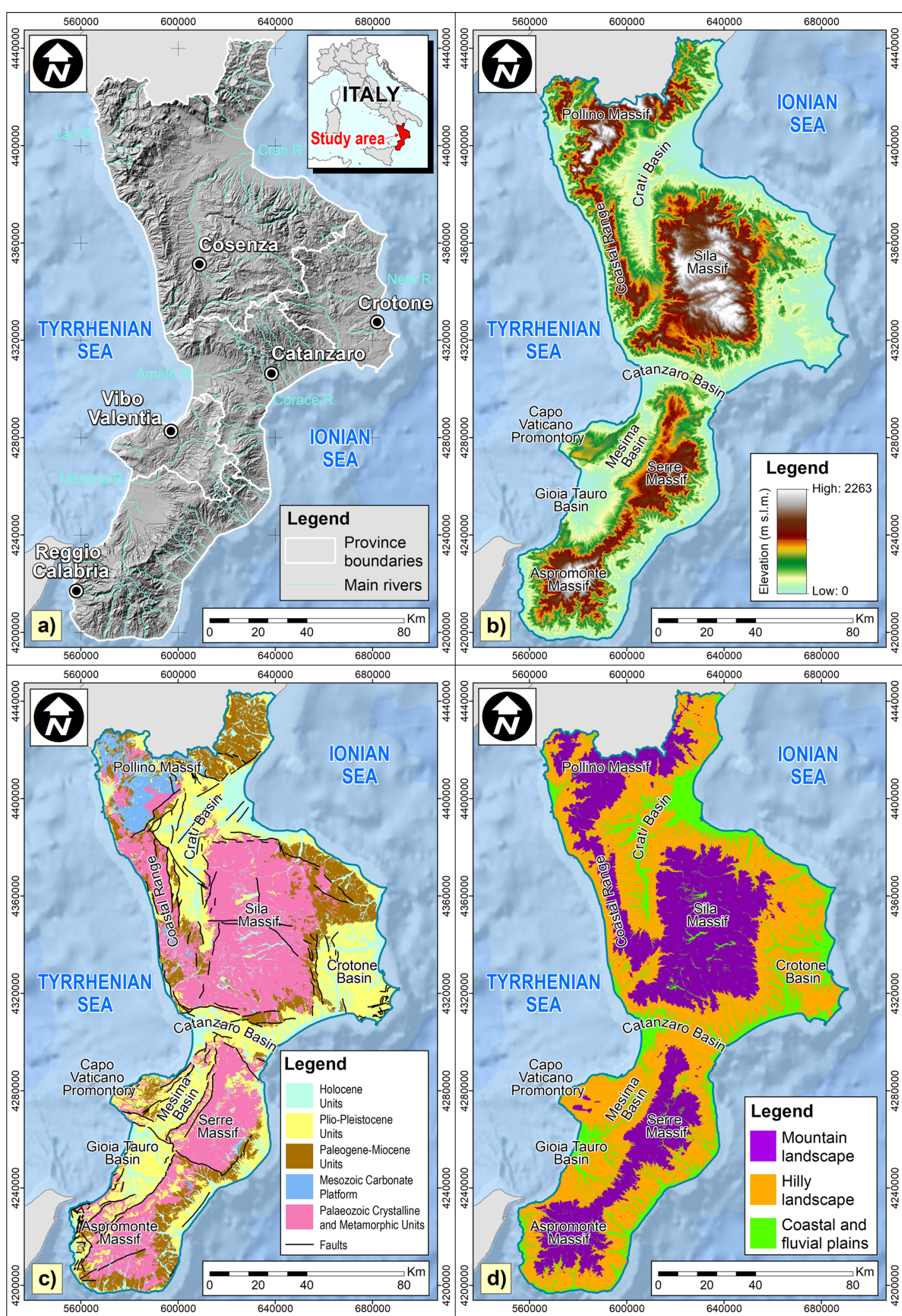

Fig. 4 Geo-environmental features of the study area (Calabria region): a hillshade relief map; b elevation map; c simplified geological and structural map (modified after Borrelli et al. 2021); d map of physiographic units 
the EVA will be a subset of the VA should one or both correction coefficients $\left(\mathrm{CC}_{\mathrm{LU}-\mathrm{S}}\right.$ and $\left.\mathrm{CC}_{\mathrm{L}-\mathrm{D}}\right)$ be lower than 1.

Finally, considering the total urban area $\left(\mathrm{UA}_{\mathrm{T}}\right)_{\mathrm{j}}$ of the $j$-th municipality in the study area, the Index of Exposure $(\mathrm{IE})_{j}$ of the $j$-th municipality (zoning unit) is computed as:

$$
(I E)_{j}=\frac{(E V A)_{j} /(E V A)_{t o t}}{\left(U A_{T}\right)_{j} /(U A)_{t o t}}
$$

In the Eq. (3) (EVA) is the equivalent vulnerable area of the $j$-th municipality, obtained by summing the EVAs associated with the same municipality; whereas (EVA) tot and (UA) tot are, respectively, the total equivalent vulnerable area and the total urban area of all the municipalities in the study area.

At small scale and with reference to the materials used, the estimated Index of Exposure (IE) allows ranking the expected detrimental effects of SMLs in VAs and, accordingly, the municipalities requiring mitigation measures.

\section{The study area}

The Calabria region, located in the southernmost part of Italy, covers about $15,075 \mathrm{~km}^{2}$ and includes five Provinces (Fig. 4a) globally counting 404 municipalities. The elevation ranges from sea level to $2263 \mathrm{~m}$ (Fig. 4b), with an average value of $523 \mathrm{~m}$.

The Calabrian climate is generally Mediterranean (Köppen 1936). The coastal zones are characterized by mild winters and hot summers (Brunetti et al. 2012; Caloiero et al. 2015). In particular, the eastern Ionian coast is drier and more arid than the western Tyrrhenian coast, which has a milder climate (Coscarelli and Caloiero 2012). On the contrary, along the inland areas of the Calabrian mountain chains, from Pollino, Sila to Aspromonte, the climate is cold in winter (with snow) and fresh in summer (Caloiero et al. 2011). The average annual precipitation ranges from $600 \mathrm{~mm}$ to more than $2000 \mathrm{~mm}$ moving from the coastal zone to internal and mountainous areas, with a mean regional value of about of $1150 \mathrm{~mm}$ (Versace et al. 1989; Terranova and Iaquinta 2011). Yearly rainfall distribution exhibits a peak from October to March when more than $70 \%$ of total annual precipitation occurs, with negligible monthly values from June to September (Terranova and Iaquinta 2011) when, however, thunderstorms can occur.
The geological setting of Calabria (Fig. 4c) consists of Palaeozoic crystalline-metamorphic units, composed of low-to-high-grade metamorphic and plutonic rocks, overthrusted during Late Cretaceous-Oligocene on the Mesozoic Apennine derived carbonate units (e.g. Amodio-Morelli et al. 1976; Tortorici 1982; Van Dijk et al. 2000), which include carbonate platform sequences of passive continental margin (Bonardi et al. 1982). Starting from the Miocene, the Calabria margins were covered by terrigenous sedimentary successions and affected, since the Tortonian, by strike-slip and extensional tectonics (Van Dijk et al. 2000). Particularly, during the Late Pliocene-Early Quaternary, several high-angle faults, both longitudinally and transversally, dissected the Calabrian Arc, developing axial intermontane and transversal basins (Ghisetti 1979; Monaco and Tortorici 2000; Sorriso-Valvo and Tansi 1996; Van Dijk et al. 2000). As a result, it was fragmented into structural highs (i.e. Pollino Massif, Coastal Range, Sila Massif, Capo Vaticano Promontory, Serre Massif-Aspromonte)-consisting of crystalline-metamorphic rocks, including phillites, schists, gneiss and granitoids (these latter manly ranging in composition from granite to tonalite)-and structural depressions (i.e. Crati basin, Catanzaro basin, Mesima, Gioia Tauro and Crotone basins) where continental and marine, coarse-grained to fine grained, depositional systems found (Fig. 4c). Furthermore, since the Middle Pleistocene, a strong regional extension, together with an intense regional uplifting, affected the whole Calabrian Arc. The Quaternary tectonic uplift-that is still ongoing, as testified by intense seismic activity (Tortorici et al. 1995) - accounts for most of the relief of the region, and the highest-relief landforms are of tectonic origin (Sorriso-Valvo 1993; Westaway 1993).

Owing to the complex geodynamic history of Calabria, linked to several tectonic phases (Tortorici et al. 1995; Tripodi et al. 2018; Van Dijk et al. 2000), the outcropping lithological units generally show physical and chemical weathering as well as high levels of fragmentation and deformation, which play an important role in the evolution of hillslopes (Biondino et al. 2018; Borrelli et al. 2015; Scarciglia et al. 2005, 2016). Furthermore, the distribution and mechanical behaviour of the lithological units influence the slope dynamics and the nature of geomorphic processes (Sorriso-Valvo 1993).

Referring to geomorphology, the Calabria region contains a great variety of morphologic and topographic

(See figure on next page.)

Fig. 5 Input data of the proposed method: a sketch of the operative grid with TCUs over the study area; $\mathbf{b}$ inventory map of the slow-moving landslides (SMLS) distinguished according to their state of activity (active and dormant); c geo-lithological setting with lithological units (LU) grouped in four classes: LU1 (coarse-grained soils, i.e. sands, sandstones, gravels, conglomerates), LU2 (carbonate rocks, i.e. limestone and dolomites), LU3 (crystalline-metamorphic rocks, i.e. phyllite, schist, gneiss, and granitoids), LU4 (fine-grained soils, i.e. silt, clay, marl); d map of average slope angles (S) distinguished in four classes: $\mathrm{S} 1 \leq 5^{\circ}, 5^{\circ}<\mathrm{S} 2 \leq 15^{\circ}, 15^{\circ}<\mathrm{S} 3 \leq 25^{\circ}, \mathrm{S} 4>25^{\circ}$; e built-up urban area (UA) map 


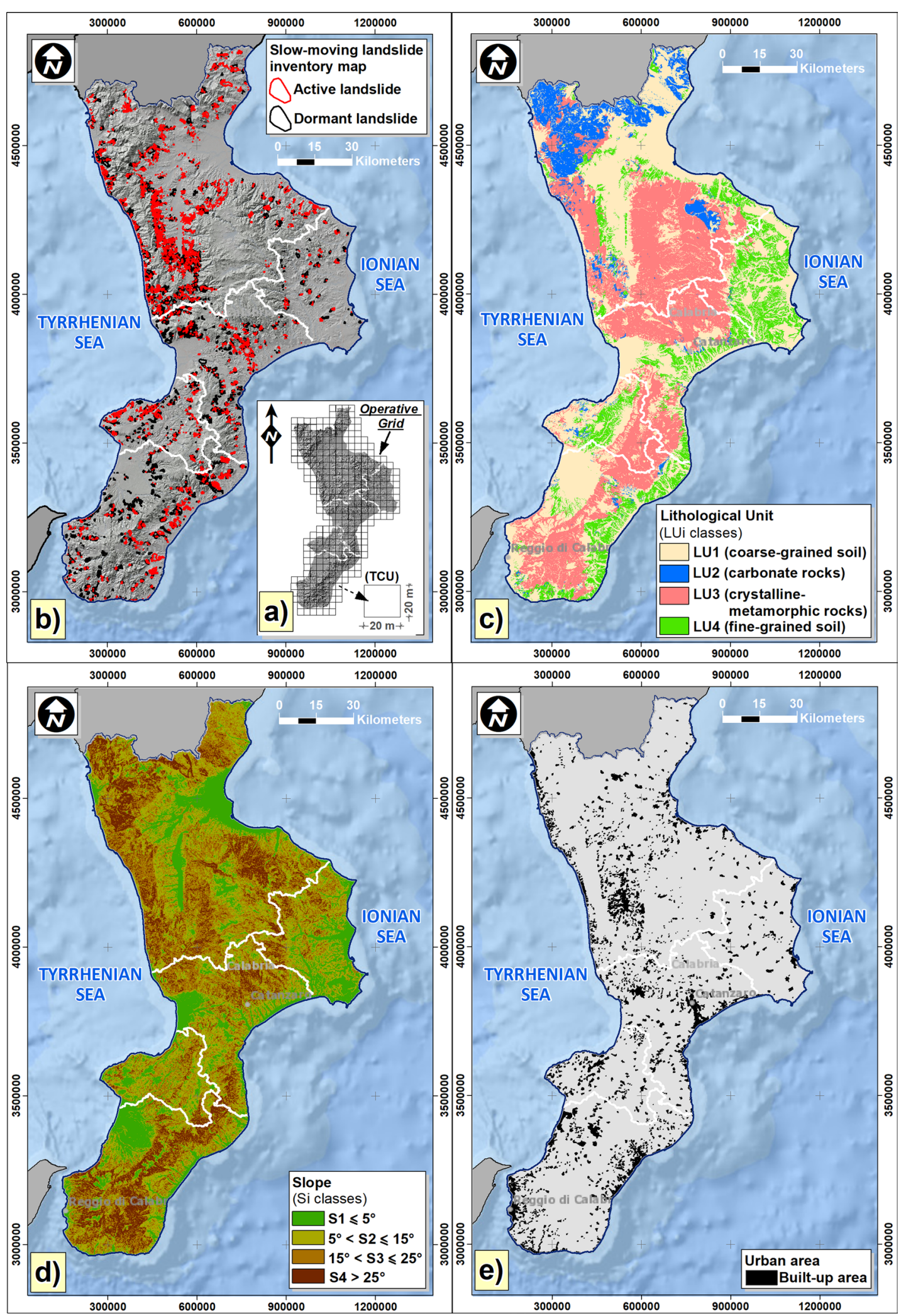

Fig. 5 (See legend on previous page.) 


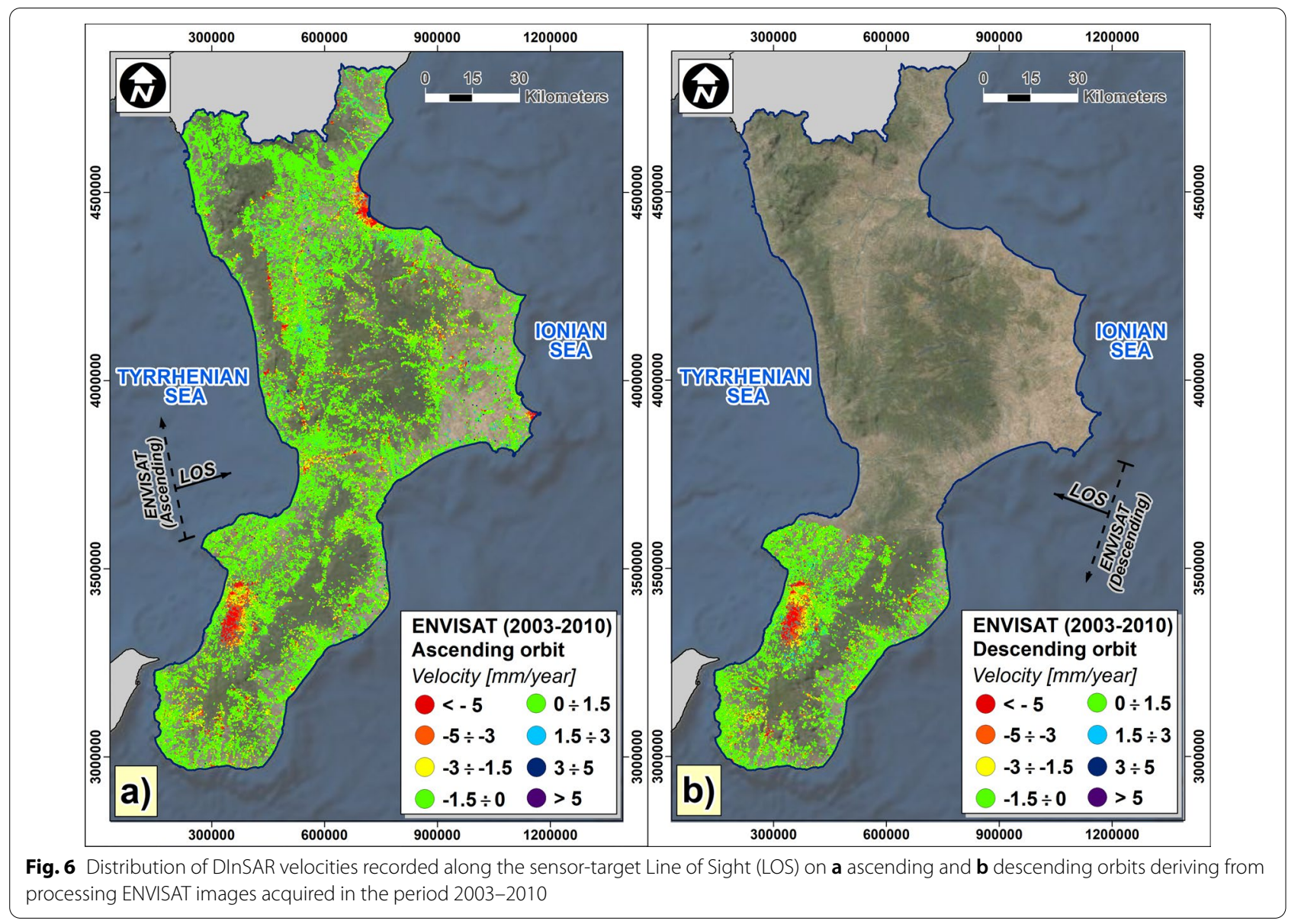

contexts, where hilly and mountain (88\% out of the total extent) prevail compared to lowlands (only 12\%) (Fig. 4d). The mountains ridges-developed on Palaeozoic metamorphic and plutonic rocks, except for the northernmost portion of the region composed by carbonate rocks-are characterized by relicts of summit planation landforms (paleosurfaces), deeply dissected and bordered by steep slopes and cut by deep and narrow valleys (e.g. V-shaped valley). The hilly areas are mainly developed on sedimentary rocks-ranging in age from Palaeogene Period to Pleistocene Epoch-of different composition and erodibility, where selective erosion has given alternatively way to steep slopes cut on hard rocks (e.g. conglomerate, sandstones and limestones) in contrast with typically rounded and gentler landscape (i.e. low-gradient slopes) characterized by pelitic, and more erodible lithologies. Finally, coastal and fluvial plains (i.e. lowland areas) are mainly constituted by loose, coarse-grained to fine grained, Holocene deposits (i.e. sands and gravel, silts, clays).

Because of its specific geological framework, tectonic history, and geomorphic landscape features, the Calabria region is very prone and widely affected by slope instability phenomena (Antronico et al. 2015; Borrelli et al. 2014, 2015, 2018a; Borrelli and Gullà 2017; Calcaterra and Parise 2010; Conforti et al. 2021; Gullà et al. 2008, 2009, 2014, 2018a; Sorriso-Valvo 1993; Sorriso-Valvo et al. 2004), mainly including SMLs that often affect both historic and newly developed built-up areas (Antronico et al. 2015; Cigna et al. 2013; Ferlisi et al. 2015; Nappo et al. 2019; Nicodemo et al. 2017b, 2020a; Peduto et al. 2017, 2018, 2021a). Detailed information, ancillary data and results of previous studies, carried out by the authors at large/detailed scale (Antronico et al. 2015, Borrelli et al. 2007, 2014, 2018b; Ferlisi et al. 2015, 2019; Gullà et al. 2014, 2017, 2018b; Nicodemo et al. 2018, 2020a; Nappo et al. 2019; Peduto et al. 2016, 2017, 2018, 2021c) are available. These data allowed taking operative assumptions for this study and a cross-validation of the outcomes achieved by applying the proposed method (Fig. 1).

\section{Results}

\section{First phase}

The first phase of the method (Fig. 1) involved associating the information pertaining to the materials with the 

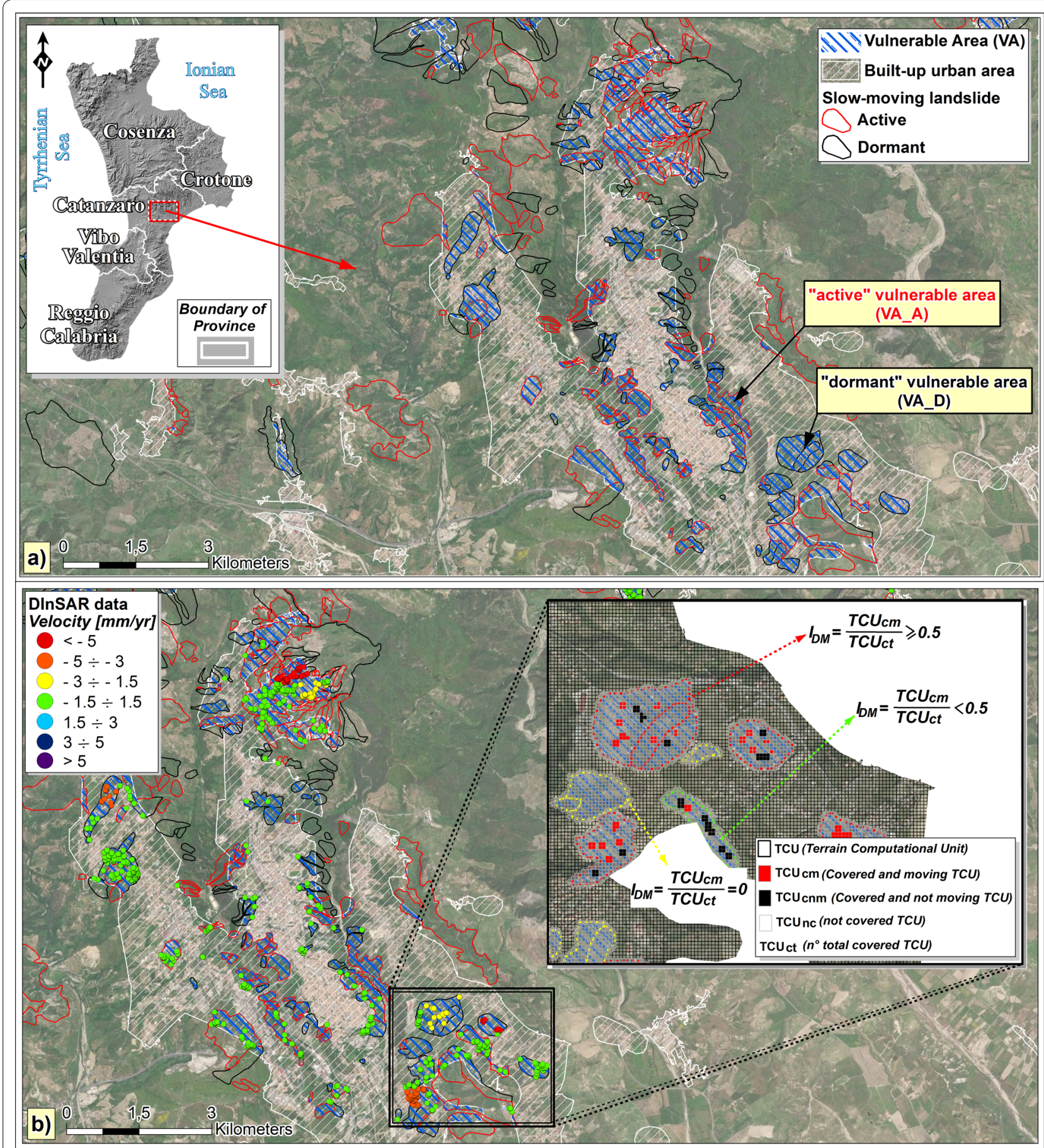

Fig. 7 Examples of vulnerable areas (VAs) deriving from the intersection of the slow-moving landslide (SML) inventory map and the built-up urban area (UA) map with indication of a "active" (VA_A) or "dormant" (VA_D) vulnerable areas distinguished according to the landslide state of activity and b possible values assumed by the Index of DInSAR-based movement $\left(\mathrm{I}_{\mathrm{DM}}\right)$

TCUs. The latter strictly correspond to squared cells $(20 \mathrm{~m} \times 20 \mathrm{~m})$ composing an operative grid overlaid to the Calabria region (Fig. 5a). The obtained input data consisted of: (i) the SML inventory map-where landslides are mapped according to their location, type and state of activity assigned by way of geomorphological criteria (Fig. 5b) - generated by filtering out fast- 


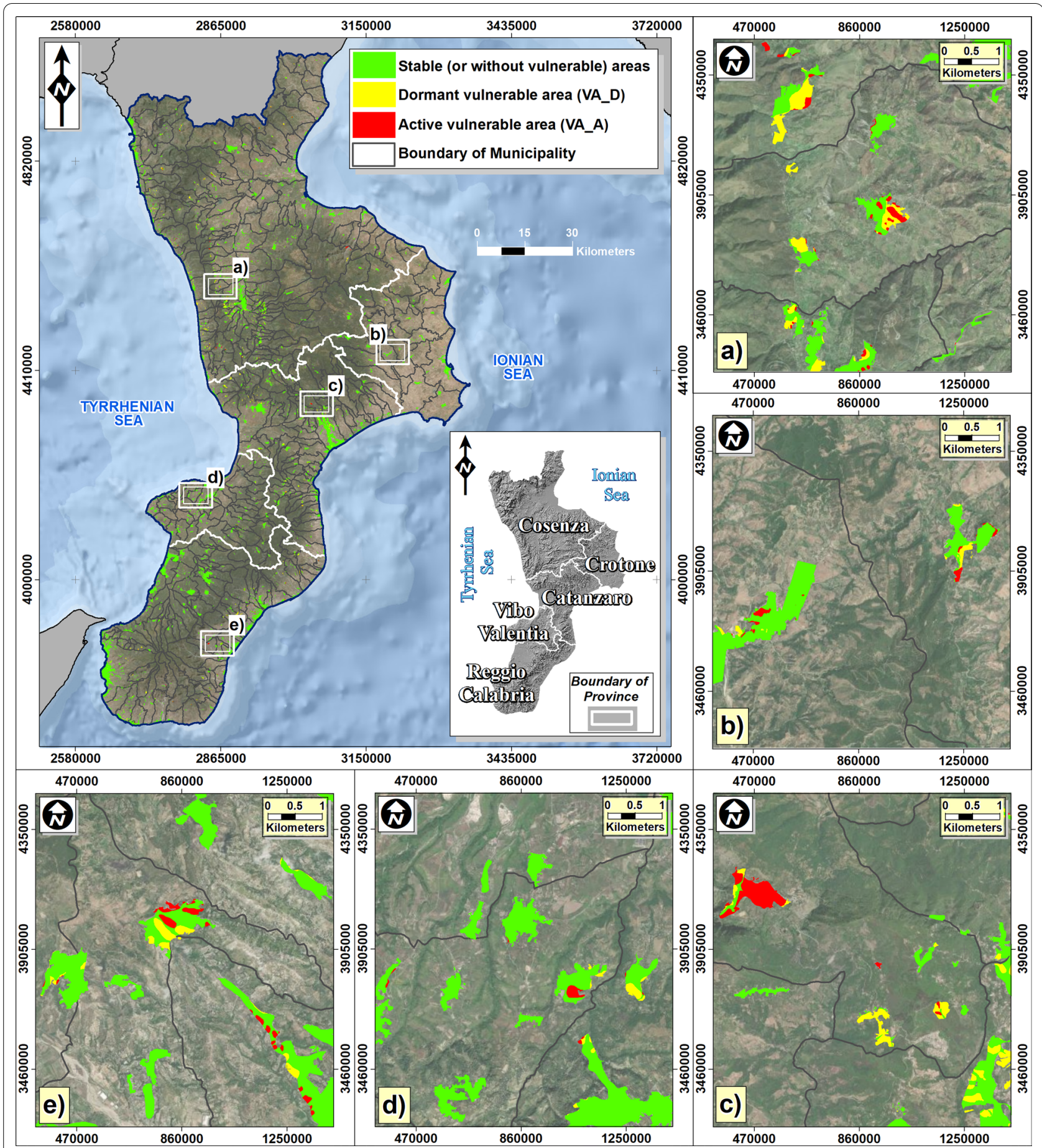

Fig. 8 A general overview of built-up areas of Calabria Region distinguished in either stable (or without VAs) and VAs (the latter are classified as active_-VA_A and dormant_-VA_D based on the state of activity of the slow-moving landslides interacting with them). The maps show some samples of built-up areas (white boxes) falling within the administrative boundaries of the five Provinces in the Calabria region: $\mathbf{a}$ Cosenza, $\mathbf{b}$ Crotone, c Catanzaro, d Vibo Valentia and e Reggio Calabria

moving landslides from the official landslide inventory map at 1.10,000 scale provided by the former Regional Basin Authority of Calabria (PAI 2016); (ii) the Lithological Unit (LU) map obtained from the Geological Map of Calabria at 1:25,000 scale (Casmez 1969) by grouping different lithologies 

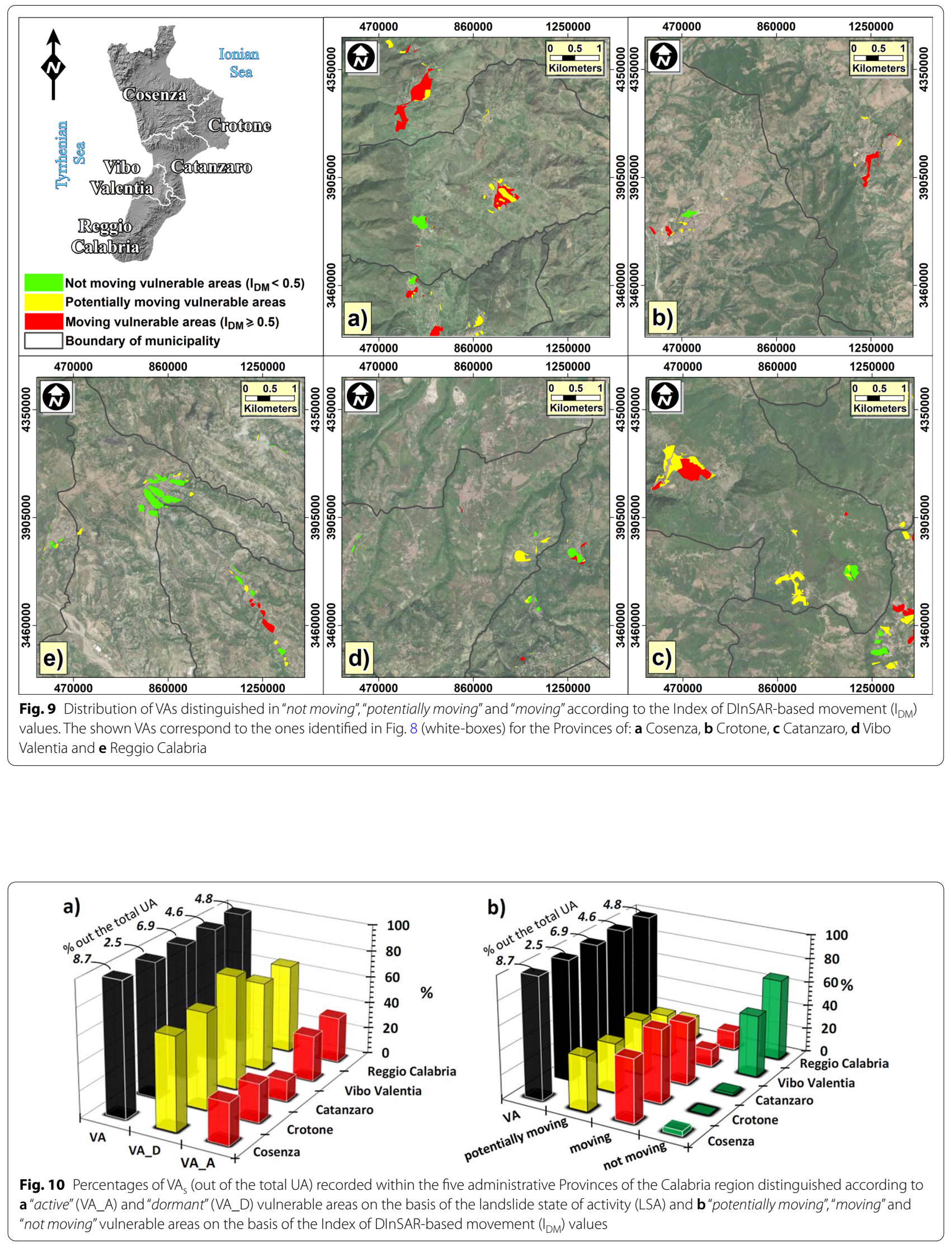


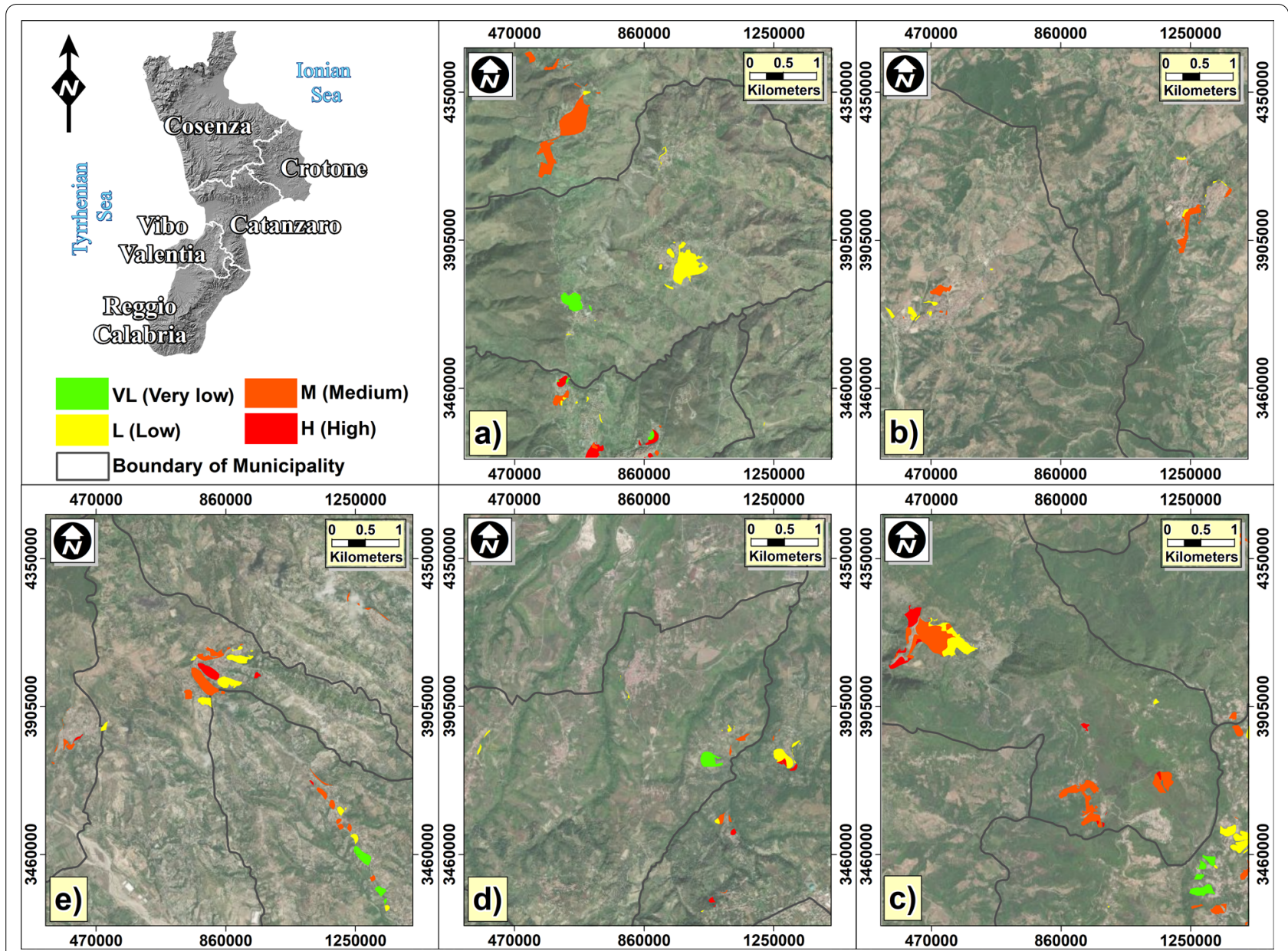

Fig. 11 An example of VAs distinguished according to the results of the Lithological consistency matrix. The sample areas correspond to the ones identified in Fig. 8 (white boxes) for the Provinces of: a Cosenza, b Crotone, c Catanzaro, d Vibo Valentia and e Reggio Calabria

into four classes based on their mechanical behaviour, regardless of their age (Fig. 5c): LU1 (coarsegrained soils, i.e. sands, sandstones, gravels, conglomerates), LU2 (carbonate rocks, i.e. limestone and dolomites), LU3 (crystalline-metamorphic rocks, i.e. phyllite, schist, gneiss, and granitoids), LU4 (fine-grained soils, i.e. silts, clays, marls), being the prevailing $\mathrm{LU}$ associated with each TCU;

(iii) the slope (S) angle map (Fig. 5d) that shows the spatial distribution of the average slope angles pertaining to the TCUs, as retrieved from the DTM with $20 \mathrm{~m}$ spatial resolution and ranked in four classes: $\mathrm{S} 1 \leq 5^{\circ} ; 5^{\circ}<\mathrm{S} 2 \leq 15^{\circ} ; 15^{\circ}<\mathrm{S} 3 \leq 25^{\circ} ; \mathrm{S} 4>25^{\circ}$, according to a statistical quantile analysis;

(iv) the presence/absence of an urban area (UA) on the TCU based on the map of built-up areas (Fig. 5e) (Open data/Geoportal Calabria region 2016).
DInSAR-derived ground displacement measurements integrated the above input data. In particular, DInSAR data were gathered from the processing of ENVISAT radar sensor images, acquired in C-band on both ascending and descending orbits, which offered the advantage of covering the whole study area (Fig. 6). The interferometric database, provided by the Italian Ministry of the Environment of the Environment and Protection of Land and Sea within the "Piano Straordinario di Telerilevamento Ambientale-PSTA" (MATTM 2010) and covering the 2003-2010 period, resulted from processing 417 ENVISAT images via the Persistent Scatterers Interferometry (PSI) technique (Ferretti et al. 2001). Starting from velocity recorded along the Line of Sight (LOS) by coherent pixels (i.e. Permanent Scatterers-PSs) over the study area (Figs. $6 \mathrm{a}$ and $6 \mathrm{~b}$ ) and considering only the PSs whose coherence exceeds 0.5 (MATTM 2010), the average velocity value (PS_av) was computed within each TCU (Peduto et al. 2015). 


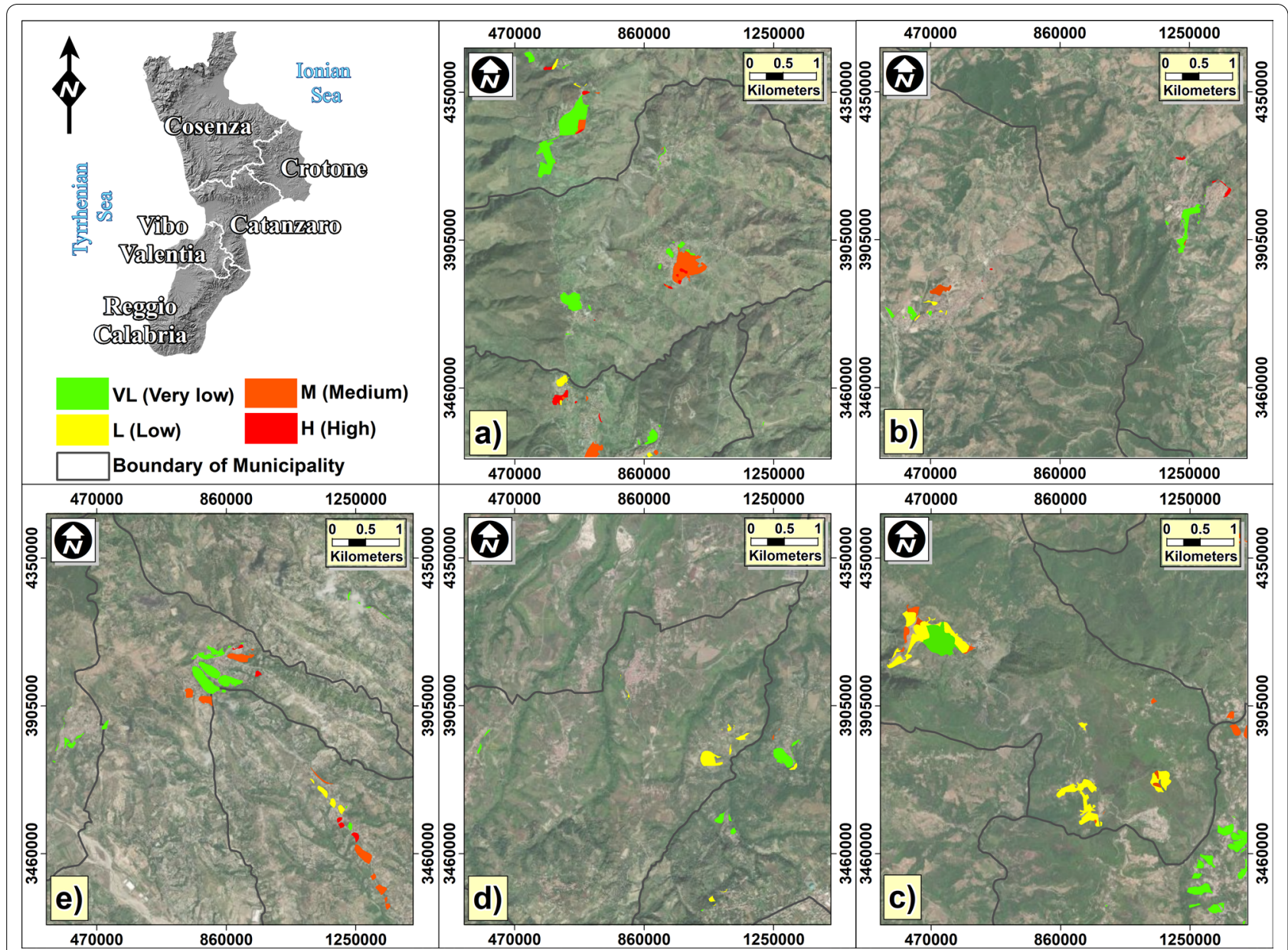

Fig. 12 An example of VAs distinguished according to the results of the Slope consistency matrix. The sample areas correspond to the ones identified in Fig. 8 (white boxes) for the Provinces of: a Cosenza, b Crotone, c Catanzaro, d Vibo Valentia and e Reggio Calabria
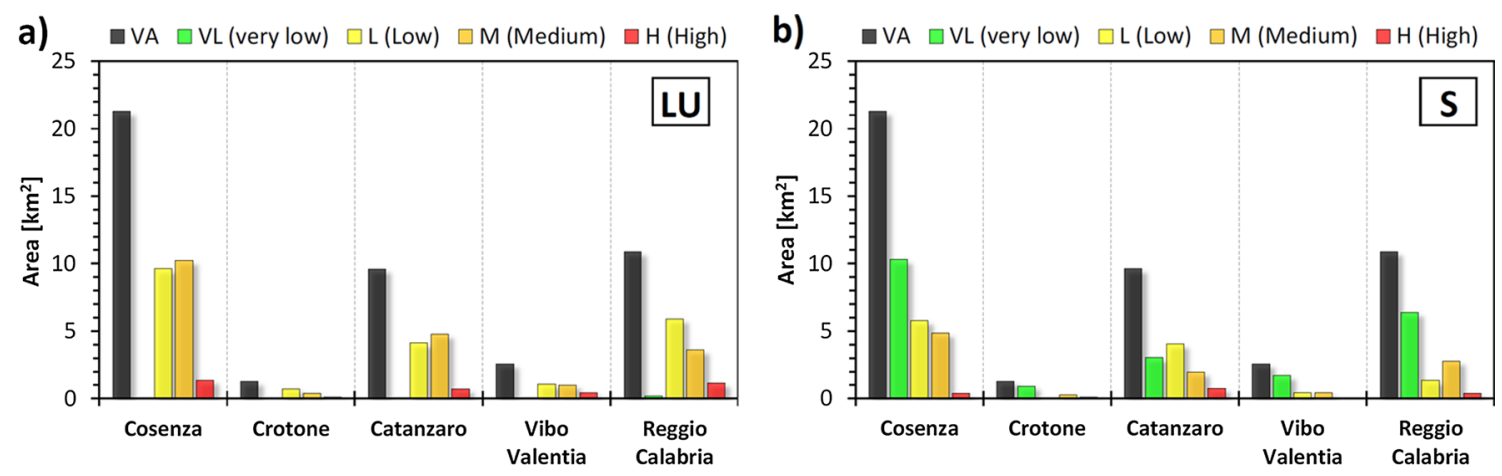

Fig. 13 Distribution of VAs recorded within the five administrative Provinces of the Calabria Region based on the qualitative indicators separately associated with $\mathbf{a} L U$ and $\mathbf{b} \mathrm{S}$ classes

\section{Second phase}

In the second phase (Fig. 1), a condition of movement (distinguished in "moving" and "not moving") was assigned to the TCUs covered by DInSAR data. To this aim, as suggested by several authors (e.g. Cascini et al. 2013; Nappo et al. 2019) according to the accuracy of DInSAR data and 
Table 1 Values of correction coefficients (CC $C_{L U-S}$ and $\left.C C_{L S A-D}\right)$ composing the Litho-Slope combination matrix and the LSA-DInSAR combination matrix

\begin{tabular}{|c|c|c|c|c|c|c|c|}
\hline \multicolumn{5}{|c|}{ Litho-Slope combination matrix } & \multicolumn{3}{|c|}{ LSA-DInSAR combination matrix } \\
\hline \multirow[t]{2}{*}{$\mathrm{CC}_{\mathrm{LU}-\mathrm{S}}$} & \multicolumn{4}{|c|}{ Slope category } & \multirow[t]{2}{*}{$\mathrm{CC}_{\text {LSA-D }}$} & \multicolumn{2}{|c|}{ DInSAR-based movement } \\
\hline & $\mathrm{VL}_{\mathrm{S}-1 / \mathrm{g}}$ & $\mathrm{L}_{\mathrm{S}-1 / \mathrm{g}}$ & $\mathrm{M}_{\mathrm{S}-\mathrm{I} / \mathrm{g}}$ & $\mathrm{H}_{\mathrm{S}-1 / \mathrm{g}}$ & & $\begin{array}{l}\text { Moving } \\
\left(\mathrm{I}_{\mathrm{DM}} \geq 0.5\right)\end{array}$ & $\begin{array}{l}\text { Not moving } \\
\left(\mathrm{I}_{\mathrm{DM}}<0.5\right)\end{array}$ \\
\hline Lithology category & & & & & $\begin{array}{l}\text { Landslide sta } \\
\text { ity (LSA) }\end{array}$ & & \\
\hline$V L_{L U-/ / g}$ & 0.25 & 0.50 & 0.50 & 0.75 & Active & 1.00 & 0.75 \\
\hline $\mathrm{L}_{\mathrm{LU}-1 / \mathrm{g}}$ & 0.50 & 0.50 & 0.75 & 0.75 & & & \\
\hline $\mathrm{M}_{\mathrm{LU}-\mathrm{I} / \mathrm{g}}$ & 0.50 & 0.75 & 0.75 & 1.00 & Dormant & 0.75 & 0.50 \\
\hline $\mathrm{H}_{\mathrm{LU}-\mathrm{I} / \mathrm{g}}$ & 0.75 & 0.75 & 1.00 & 1.00 & & & \\
\hline
\end{tabular}

taking into account the results of quantitative validation tests carried out on DInSAR data based on conventional ground measurements (Nicodemo et al. 2017a; Peduto et al., 2018), a threshold value on the average annual velocity recorded along the LOS equal to $1.5 \mathrm{~mm}$ /year was fixed. Then, a given TCU was considered as: "moving" if the average DInSAR velocity of the PSs within it exceeded the fixed threshold of $1.5 \mathrm{~mm} /$ year (Cascini et al. 2013); "not moving" if the threshold of $1.5 \mathrm{~mm}$ /year was not exceeded; "not covered" if no DInSAR information on the TCU was recorded.

Then, the SML inventory map (Fig. 5b) was overlaid to the UA map (Fig. 5e) to identify the VAs of the study area. Each VA, in turn, was categorised as "active" (VA_A) or "dormant" (VA_D) according to the state of activity of the pertaining SML (Fig. 7a); whereas the built-up areas not affected by SMLs were considered as stable or without vulnerable areas (SA). An example of some built-up areas included within the administrative boundaries of the five Provinces in Calabria region is shown in Fig. 8.

On the other hand, based on the values of the $I_{D M}$ (Fig. 7b) computed using Eq. (1) the identified VAs were classified as "potentially moving", "moving" or "not moving". In this regard, an example is shown in Fig. 9.

The results obtained by applying the first step of the second phase of the proposed method for each of the five Provinces of Calabria region are summarised in Fig. 10. In particular, the VAs (expressed as a percentage of the total UA pertaining to each Province) are distinguished according to either the state of activity of SMLs they are affected by (Fig. 10a) or the $\mathrm{I}_{\mathrm{DM}}$ values (Fig. 10b).

The second step of the second phase of the proposed method is aimed at associating each VA with qualitative indicators of the consequences expected to the built-up environment due to LUs and Ss (Very LowVL, Low-L, Medium-M, and High-H). To this aim, based on the experience (i.e. phenomenological observation and monitoring data) gained on the study area (Antronico et al. 2013; Borrelli et al. 2014, 2018b; Borrelli and Gullà 2017; Gullà 2014; Gullà et al. 2010, 2012, 2017, 2018a, b; Peduto et al. 2016, 2021b), the LU classes were ranked as LU1:VL, LU2:L, LU3:M, LU4:H (see Fig. 3a and Fig. 5c) and the S classes as S1:VL, S2:L, S3:M, S4:H (see Fig. 3b and Fig. 5d). Then, the "Lithological consistency matrix" (for LU) and the "Slope consistency matrix" (for S) were used to assign to each VA the proneness category (Fig. 3a, b) also considering both the local (referred to the VA) and global (referred to the whole SML interacting with the VA) effects. Two examples of the achieved results are shown in Figs. 11 and 12 that refer to the application of the "Lithological consistency matrix" and the "Slope consistency matrix", respectively.

The results of this part allowed computing the extent of VAs within the five Provinces of Calabria region according to the qualitative indicators separately associated with LU (Fig. 13a) and S (Fig. 13b) classes.

\section{Third phase}

The third phase of the proposed method focused on:

(i) heuristically assigning the values pertaining to the Correction Coefficients $\left(\mathrm{CC}_{\mathrm{LU}-\mathrm{S}}\right.$ and $\left.\mathrm{CC}_{\mathrm{LSA}-\mathrm{D}}\right)$ composing either the Litho-Slope combination matrix (Fig. 3c) or the LSA-DInSAR combination matrix (Fig. 3d);

(ii) calculating the Equivalent Vulnerable Area (EVA);

(iii) evaluating the Index of Exposure (IE).

In this regard, Table 1 shows the values attributed to the Correction Coefficients for the Litho-Slope combination matrix and the LSA-DInSAR combination matrix, respectively. On the other hand, EVA pertaining to each VA was estimated according to the Eq. (2). 

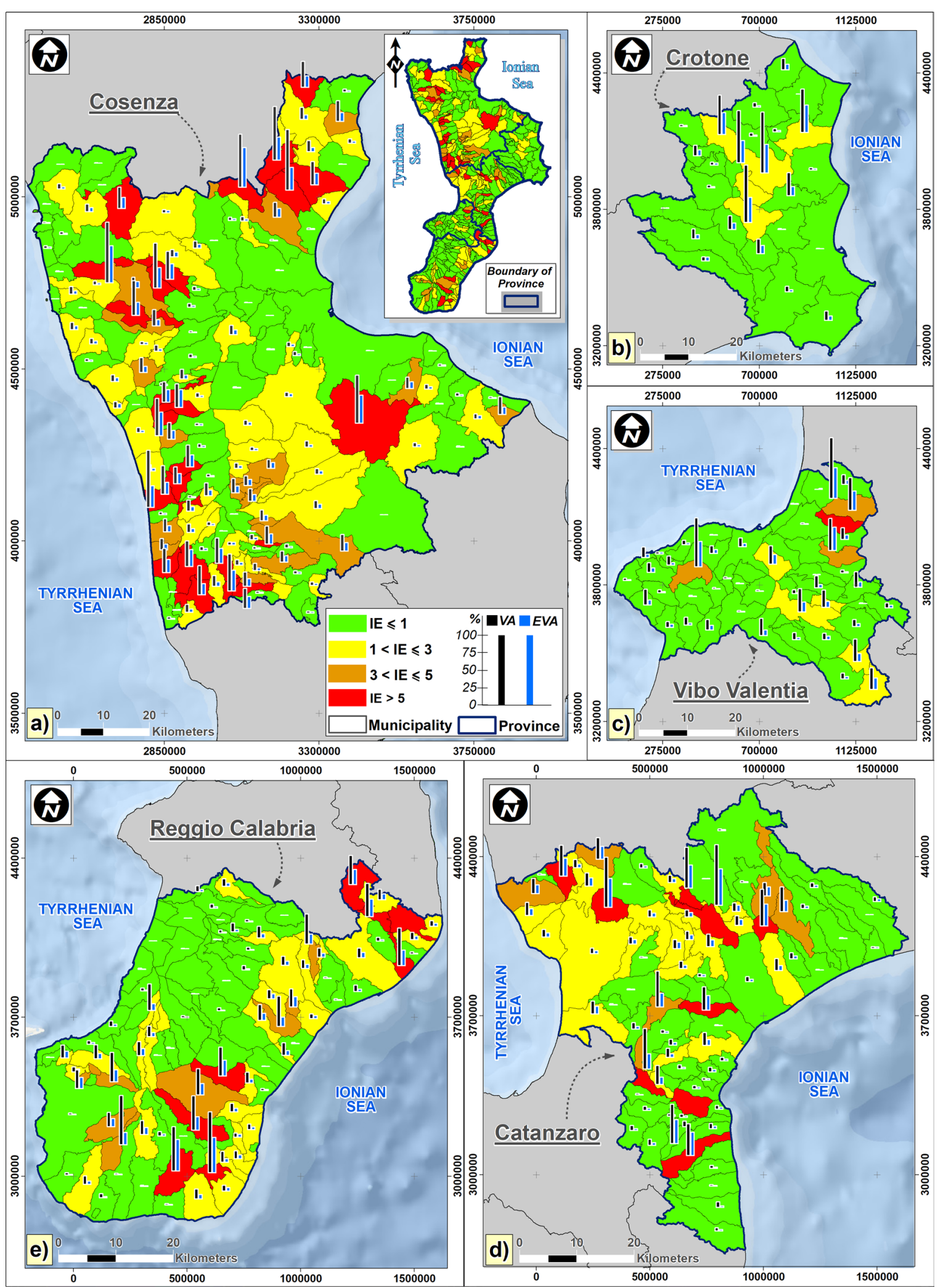

Fig. 14 Map of the municipalities (zoning units) of Calabria region distinguished according to the index of exposure (IE) values with the percentage of vulnerable area (VA) and Equivalent Vulnerable Area (EVA) for the Provinces of: a Cosenza, b Crotone, c Vibo Valentia, $\mathbf{d}$ Catanzaro and e Reggio Calabria 


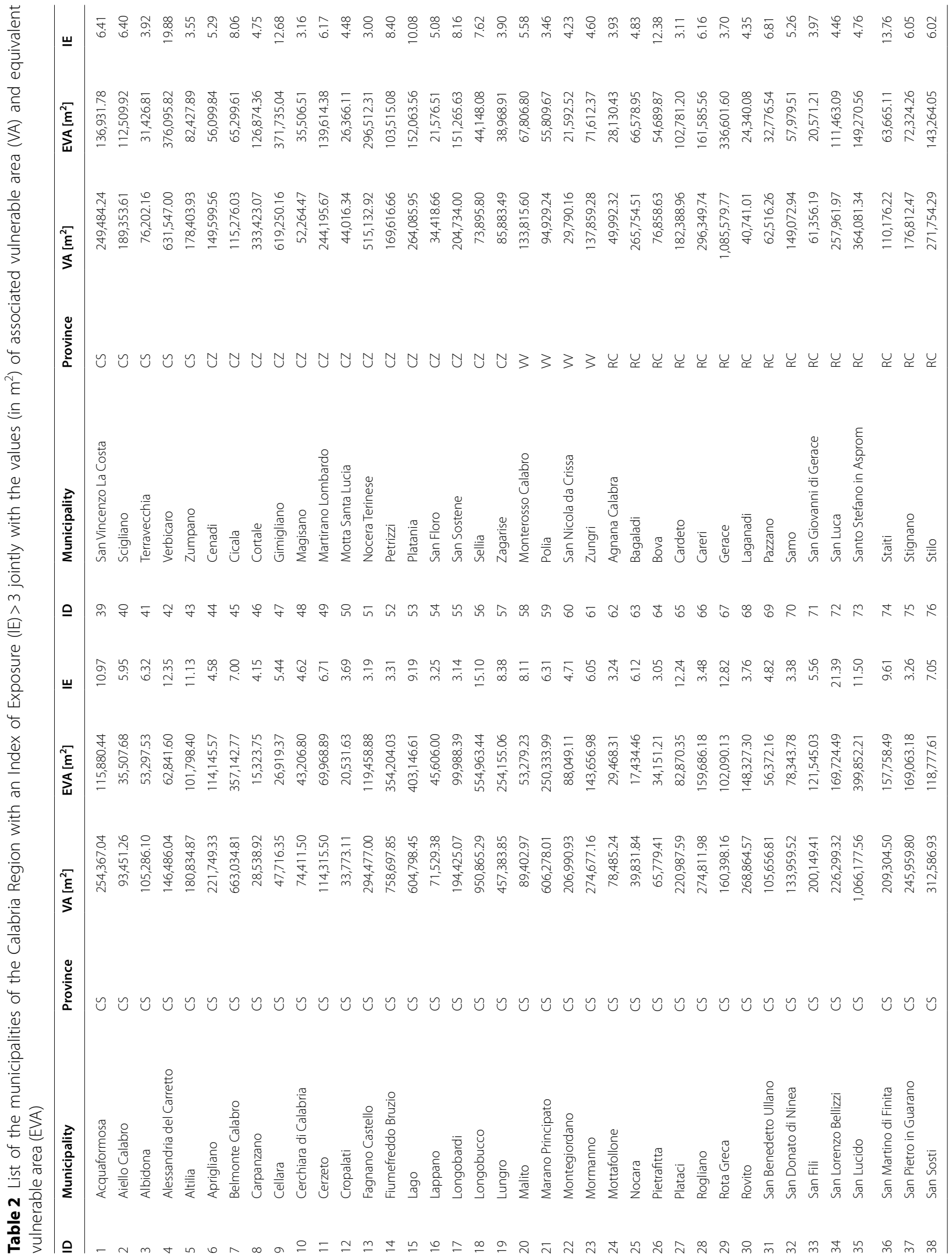


Finally, the IE for the $j$-th municipality was computed using the Eq. (3), provided that Total Urban Areas $\left(\mathrm{UA}_{\mathrm{T}}\right)$ pertaining to each municipality had been preliminarily estimated.

Figure 14 shows the municipalities of Calabria region distinguished according to IE values with the percentage of VA and EVA for the Provinces of: Cosenza (Fig. 14a), Crotone (Fig. 14b), Vibo Valentia (Fig. 14c), Catanzaro (Fig. 14d) and Reggio Calabria (Fig. 14e). Table 2 summarises the municipalities of Calabria region with $\mathrm{IE}>3$ along with the values of the resulting VA and EVA (in $\mathrm{m}^{2}$ ).

\section{Validation tests}

The results obtained were validated by way of a comparison with the results-including damage to buildings in VAs - gathered from previous studies in four municipalities of Calabria region where LU3 prevails, namely: Lungro and Verbicaro in Cosenza Province (Antronico et al. 2015; Borrelli et al. 2018b; Ferlisi et al. 2015; Gullà et al. 2017; Nicodemo et al. 2017b, 2018, 2020a; Peduto et al. 2017, 2018, 2021a,c), Gimigliano (Bianchini et al. 2013) and San Mango d'Aquino (Gullà et al. 2010) in Catanzaro Province. The application of the proposed method (Fig. 1) provided IE values larger than 8 for three out of the four selected municipalities (Table 2 and Fig. 14): Verbicaro (IE = 19.88), Gimigliano (IE = 12.68) and Lungro (IE =8.38). On the other hand, an IE value lower than 1 (Fig. 14) was recorded for San Mango D'Aquino $(\mathrm{IE}=0.22)$.

As for the damage to buildings, the data collected for the four municipalities under consideration resulted from surveys carried out in October 2015 in Lungro (Peduto et al. 2016, 2017), in April-May 2014 in Verbicaro (Ferlisi et al. 2015; Nicodemo et al. 2017b), and in August 2017 in Gimigliano and San Mango D'Aquino (Vitale 2017). To this aim, ad-hoc predisposed factsheets were filled in (Ferlisi et al. 2015; Nicodemo et al. 2017b) also specifying the damage severity level recorded to the surveyed building according to a classification system adapted from Burland et al. (1977). Particularly, this classification system distinguishes six damage severity levels $(\mathrm{D} 0=$ negligible, $\mathrm{D} 1=$ very slight, $\quad$ 22 = slight; $\quad$ D3 = moderate; $\quad$ D4 = severe; D5 = very severe) according to the width of cracks and their distribution on building façades as well as to the easy of repair. Generally, the attainment of:

(i) the D0-D1-D2 severity levels implies effects on the building aesthetics;

(ii) the D3-D4 severity levels may determine a loss of functionality;

(iii) the D5 severity level may compromise the building stability.

Overall, 2240 buildings were surveyed (211 in Lungro, 395 in Verbicaro, 711 in Gimigliano, and 923 in San Mango D’Aquino).

Figures $15 \mathrm{a}-\mathrm{c}$ respectively show the spatial distribution of the recorded damage severity levels in Lungro, Verbicaro and Gimigliano, with some examples of the crack patterns recorded in the buildings surveyed within the identified VAs, the latter distinguished in dormant (VA_D) and active (VA_A) (Fig. 8).

The pie charts of the damage severity levels in the three municipalities (Fig. 15d) show that Verbicaro is the municipality with the highest percentage of buildings with a recorded damage exceeding the D0 severity level $(40.3 \%$ out of the total, Fig. 15d), followed by Lungro (39.4\% out of the total, Fig. 15d) and Gimigliano (18.8\% out of the total, Fig. $15 d$ ).

Considering the surveyed buildings that are distributed over the VAs, Fig. 15e1 highlights that in Lungro the $67.4 \%$ of them is within VA_D whereas the remaining $32.6 \%$ is within VA_A. These buildings exhibit damage severity levels exceeding D0 according to the following percentages (out of the total): $\mathrm{D} 1=14.0 \%$; $\mathrm{D} 2=7.2 \%$; D3 = 8.6\%; D4 = 3.6\%; D5 = 5.9\%.

In Verbicaro the $36.7 \%$ of surveyed buildings is within VA_D and the remaining 63.3\% in VA_A (Fig. 15e1). Among these buildings, the $40.3 \%$ out of the total exhibits the following damage severity levels: $D 1=19 \%$; D2 $=8.9 \%$; D3 =6.6\%; D4 = 3.0\%; D5 $=2.8 \%$.

In Gimigliano the $10.7 \%$ of surveyed buildings is within VA_D and the remaining $89.3 \%$ is in VA_A (Fig. 15e1), being the $18.8 \%$ out of the total with the following damage severity levels: $\mathrm{D} 1=13.1 \% ; \mathrm{D} 2=3.5 \%$; $\mathrm{D} 3=0.7 \%$; D4 $=0.8 \%$; D5 $=0.7 \%$.

Figure $15 \mathrm{e} 2$ provides the distribution of the damage severity levels exceeding Do considering separately the VA_D and VA_A for each municipality. The data confirm

(See figure on next page.)

Fig. 15 Maps of three selected municipalities (zoning units) of Calabria region exhibiting a high value of the Index of Exposure (IE): a Lungro $(\mathrm{IE}=8.38)$, $\mathbf{b}$ Verbicaro $(\mathrm{IE}=19.88)$ and $\mathbf{c}$ Gimigliano $(\mathrm{IE}=12.68)$. The maps highlight the Urban Areas (UA) of each municipality overlapped to the identified stable (or without vulnerable) areas (SAs) and vulnerable (VAs)—distinguished in "active" (VA_A) or "dormant" (VA_D) areas—with buildings classified according to the recorded damage severity level and some examples of observed crack patterns collected during in-situ surveys. The percentages of the recorded building damage severity levels located over the identified VA are shown in d) jointly with their distribution based on e1) the total UA (divided in SA, VA_D and VA_A) and e2) the single (SA,VA_D and VA_A) area (percentages pertain to each municipality) 


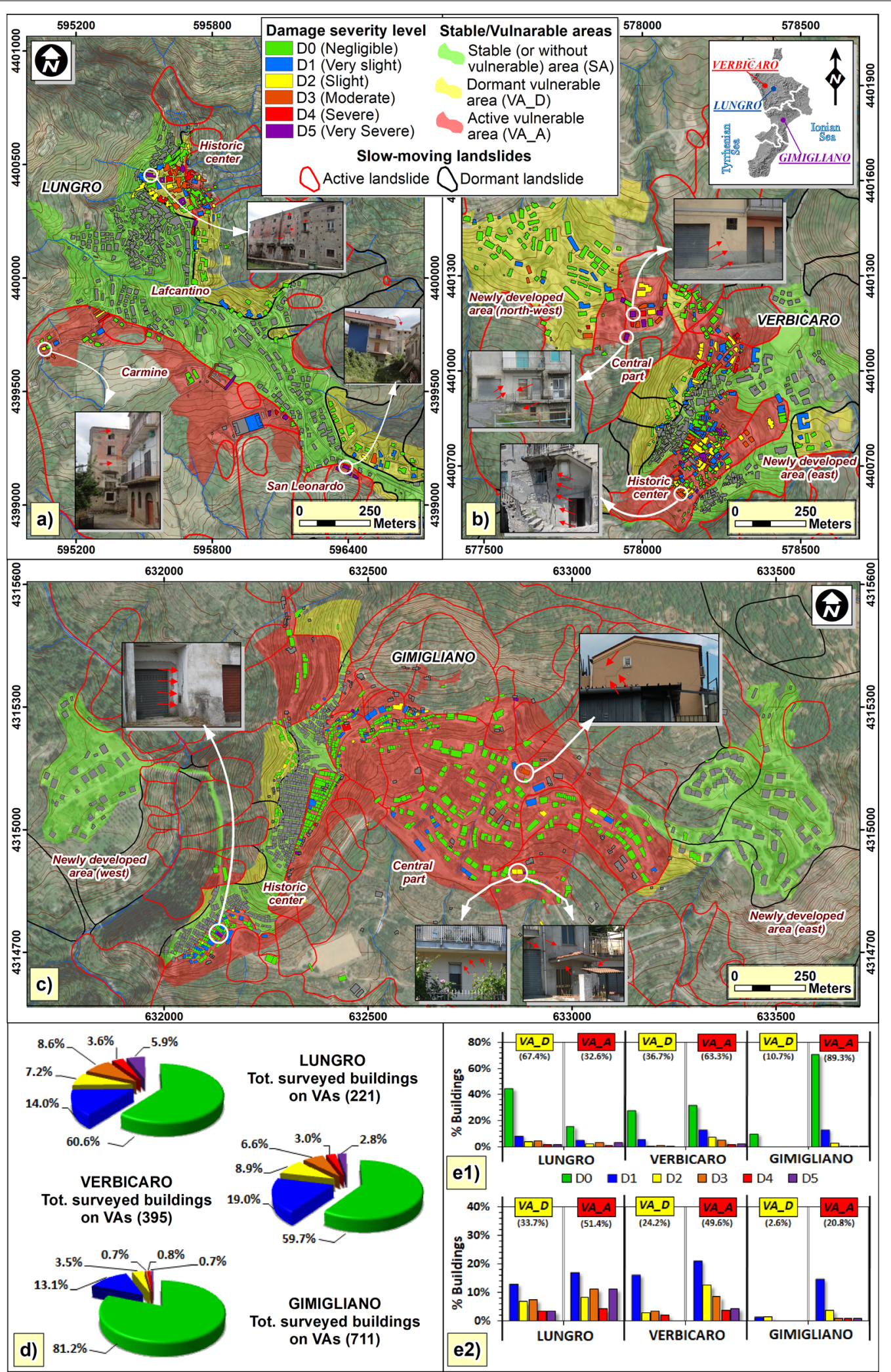

Fig. 15 (See legend on previous page.) 
Table 3 Ranking of the level of exposure to SMLs of four selected municipalities

\begin{tabular}{|c|c|c|c|c|c|c|}
\hline \multirow{3}{*}{$\begin{array}{l}\text { Municipality } \\
\\
\text { Lungro } \\
(\mathrm{IE}=8.38)\end{array}$} & \multirow{3}{*}{$\begin{array}{l}\text { Number of surveyed } \\
\text { buildings } \\
211\end{array}$} & \multicolumn{2}{|c|}{$\begin{array}{l}\text { Number of buildings (in } \\
\text { percentage) whose recorded } \\
\text { damage severity levels belong to a } \\
\text { given macro-class }\end{array}$} & \multirow{2}{*}{$\begin{array}{l}\mathrm{D}_{\mathrm{av}} \\
1.239\end{array}$} & \multirow{2}{*}{$\begin{array}{l}\mathrm{VA} / \mathrm{UA}_{\mathrm{T}} \\
0.4621\end{array}$} & \multirow{2}{*}{$\begin{array}{l}\mathrm{D}_{\mathrm{av}} \times \mathrm{VA} / \mathrm{UA}_{\mathrm{T}} \\
0.573\end{array}$} \\
\hline & & D0-D1-D2 & $81.9 \%$ & & & \\
\hline & & D3-D4 & $12.2 \%$ & & & \\
\hline & & D5 & $5.9 \%$ & & & \\
\hline \multirow{3}{*}{$\begin{array}{l}\text { Verbicaro } \\
(\mathrm{IE}=19.88)\end{array}$} & 395 & D0-D1-D2 & $87.6 \%$ & 1.152 & 0.9571 & 1.103 \\
\hline & & D3-D4 & $9.6 \%$ & & & \\
\hline & & D5 & $2.8 \%$ & & & \\
\hline \multirow{3}{*}{$\begin{array}{l}\text { Gimigliano } \\
(\mathrm{IE}=12.68)\end{array}$} & 711 & D0-D1-D2 & $97.8 \%$ & 1.029 & 0.6471 & 0.666 \\
\hline & & D3-D4 & $1.5 \%$ & & & \\
\hline & & D5 & $0.7 \%$ & & & \\
\hline \multirow{3}{*}{$\begin{array}{l}\text { San Mango D'Aquino } \\
(\mathrm{IE}=0.22)\end{array}$} & 923 & D0-D1-D2 & $98.9 \%$ & 1.012 & 0.0174 & 0.018 \\
\hline & & D3-D4 & $0.8 \%$ & & & \\
\hline & & D5 & $0.3 \%$ & & & \\
\hline
\end{tabular}

that Verbicaro is the municipality mostly affected by SMLs.

Based on the gathered damage data, it is possible to estimate a value representative of the damage severity level averagely recorded at the municipality scale $\left(D_{\mathrm{av}}\right)$. To this aim, a numerical index was associated with the macro-classes of damage severity related to a given loss (i.e. aesthetic, functionality, stability); in this regard, the adopted numerical indices equalled 1, 2 and 3 for the macro-classes D0-D1-D2, D3-D4 and D5, respectively. Then, $D_{a v}$ was estimated as the average of the above indices weighted on the number of buildings whose recorded damage severity levels belong to a given macro-class. Finally, the obtained $\mathrm{D}_{\mathrm{av}}$ value was multiplied by the dimensionless ratio of the VA with the $\mathrm{UA}_{\mathrm{T}}$ to take into account the extent of the areal exposure of a given municipality. The obtained results are synthesised in Table 3. It is worth observing that they are ranked according to the IE values retrieved at small scale, so confirming the reliability of the proposed method.

A similar analysis was carried out for San Mango d'Aquino municipality (Fig. 16a) whose territory is affected by several SMLs (Fig. 16b), being the urban area mainly resting on a deep-seated gravitational slope deformation (DGSD). Figure 16c shows the results in terms of spatial distribution of recorded damages within the areas identified as VAs in Fig. 8.

The outcomes achieved for San Mango D'Aquino confirms the reliability of the proposed method in ranking the zoning units based on the expected detrimental effects of the SMLs on VAs. Indeed, from the pie chart (Fig. 16d) and the damage distribution concerning either the whole $\mathrm{UA}_{\mathrm{T}}$ (divided in VA_D and VA_A, Fig. 16e1) or, separately, the VA_D and VA_A (see Fig. 16e2), it is evident that most of the surveyed buildings exhibit a negligible damage (D0) or show damage severity levels between D1 and D2 classes. Furthermore, the pertaining product $\mathrm{D}_{\mathrm{av}} \times \mathrm{VA} / \mathrm{UA}_{\mathrm{T}}$ equals 0.018 , namely the lowest value obtained for the four tested municipalities (Table 3).

\section{Discussion and conclusions}

This paper presented the results of a study aimed at ranking-at small scale-the municipalities of the Calabria region (southern Italy) based on their exposure to SML risk. To this aim, a three-phase method was applied on the basis of the available base materials (i.e. topographic and thematic maps, DInSAR data) the quality of which strongly affects the reliability of the outcomes. As for the SML inventory map, the regular updating is required to guarantee its completeness over time (van Westen et al. 2006). In this regard, the use of DInSAR data may profitably help the involved scientists/technicians, even at small scale (Boni et al. 2020; Raspini et al. 2019). On the other hand, with the general intent to setup an operative tool for central and local authorities in charge of SML risk management based on the proposed three-phase method, using updated base materials is a prerequisite. Currently, this aspect represents one of the limits to the straightforward applicability of the three-phase method in Calabria region (and in other regions of Italy affected by SMLs as well). As for DInSAR data, for instance, they were gathered from the processing of ENVISAT radar sensor images, acquired on both ascending and descending orbits. This interferometric database, provided by MATTM (2010), offered the advantage of covering the 


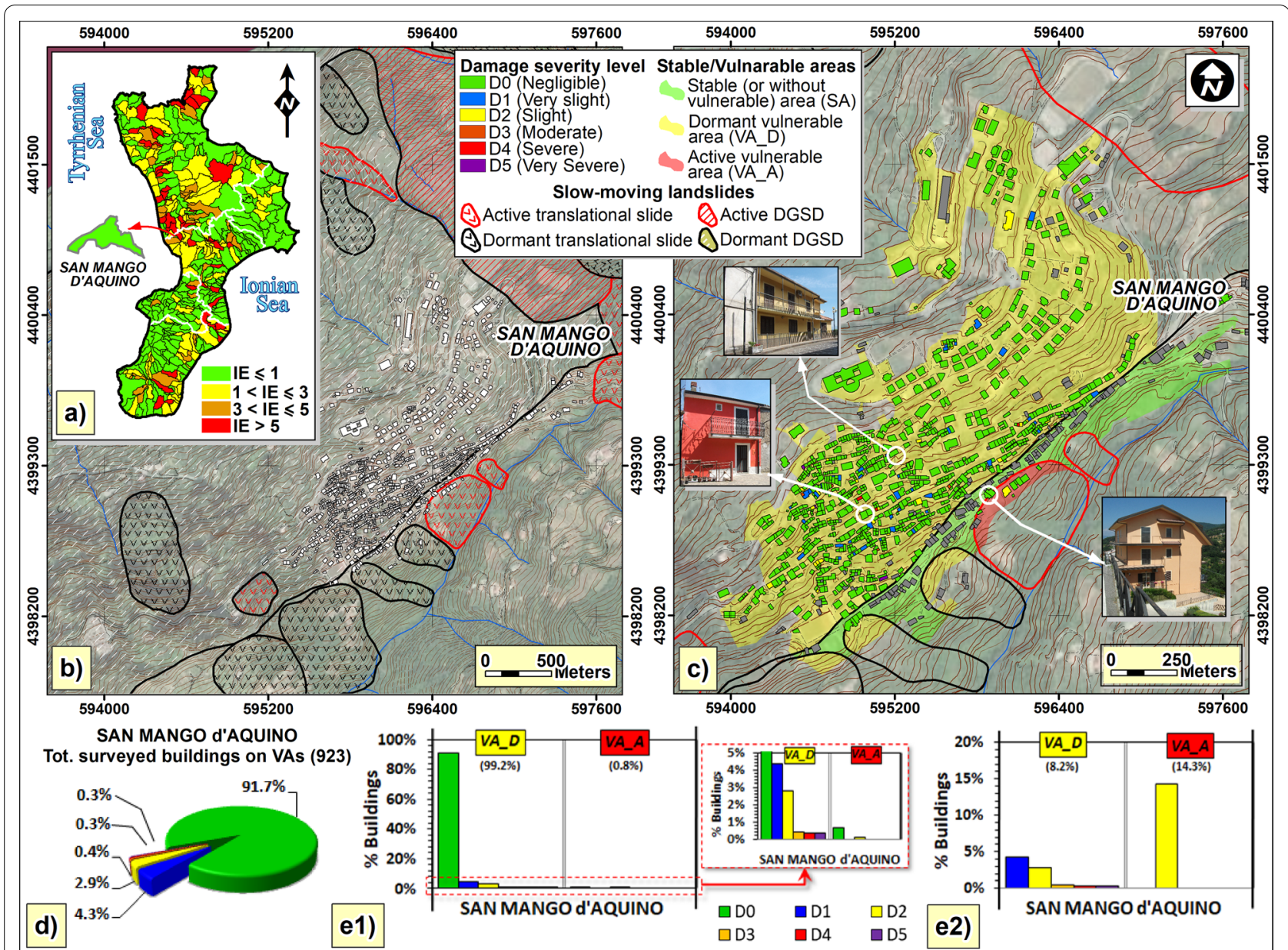

Fig. 16 Maps of San Mango d'Aquino municipality exhibiting a low value of the Index of Exposure (IE=0.22): a map of Calabria Region municipalities (zoning units) distinguished according to the IE values; b slow-moving landslide (SML) inventory map; $\mathbf{c}$ map of the Urban Areas (UA) overlapped to the identified stable (or without vulnerable) areas (SAs) and vulnerable (VAs)—distinguished in "active" (VA_A) or "dormant" (VA_D) areas - with buildings classified according to the recorded damage severity level and some photos of buildings taken during in-situ surveys. The percentages of the recorded buildings damage severity levels located over the identified VA are shown in d) jointly with their distribution based on e1) the total UA (divided in SA, VA_D and VA_A) and e2) the single (SA,VA_D and VA_A) area

whole territory of Calabria region. Unluckily, the more recent COSMO-SkyMed dataset available for Calabria region within the PST-A project currently provides just a limited coverage. Similarly, processed Sentinel data are not yet available.

DInSAR data may also assist in activities aimed at monitoring SMLs and the built environment at large/detailed scale (Fell et al. 2008), especially when very high-resolution images are available (Bianchini et al. 2015; Nicodemo et al. 2020a, b; Peduto et al. 2017, 2018, 2019a). If detected "moving buildings" are outside the boundaries of SMLs mapped in an official inventory, before appointing them as VAs the presence of not-mapped SMLs should be ascertained (and the inventory map updated) as the cause of the recorded DInSAR-based displacements to avoid including in the analysis buildings that are suffering, for instance, from structural problems. Accordingly, the possibility of including DInSAR moving areas out of mapped SMLs in the sample of VA should bring along considerations on the reliability of the available official inventory that, however, is out of the scope of this paper.

As for the validation of the results obtained, which focused on four municipalities of the Calabria region, interestingly, a wider and longer-lasting test could be carried out by way of the use of innovative tools such as Google Street View (Ferlisi et al. 2021; Nappo et al. 2019). This would allow a multi-temporal check of crack patterns of building façades in the analysed VAs in a rapid, easy, and cost-effective way. Moreover, coeval updated 
SML inventory map/DInSAR data and damage information may be available and, accordingly, SML displacements and related effects on exposed buildings would be properly used for validation purposes. Conversely, the current coverage limitations of Google Street View could limit its application in those countries (e.g. in Eastern Europe, most of the Middle East, Africa) where related images are not fully available yet.

Once validated, the results obtained at small scale can facilitate central/local authorities in selecting the areas, with homogeneous geo-lithological assets and urban fabrics, where in-depth activities (including geotechnical investigations and modelling) must be carried out at larger scales to identify SMLs having typified features (Gullà et al. 2017) and, accordingly, choose the intervention categories that prove to be more effective in mitigating the risk. In this regard, inventorying the interventions already put in place might provide useful information in decision making processes, provided that their effectiveness has been checked by way of monitoring activities corroborated by field surveys (Infante et al. 2020; Maino et al. 2021; Nicodemo et al. 2020a). Anyway, implementing the interventions may be difficult considering that it depends upon several issues among which the earmarked economic resources (often limited) must be mentioned.

Owing to the complexity of the issue, circular approaches-of which the proposed method could be a part-can represent the solution (Ferlisi et al. 2019). As a rule, circular approaches should involve:

(i) at each scale, periodically updating methods and results (and, accordingly, decisions) as quality and quantity of input data increase thanks to information gathered from monitoring and field surveys/ investigations;

(ii) from small to detailed scales and vice-versa, using knowledge acquired at a given scale to improve the knowledge at another scale, so making decisions (on how, where and when to intervene) more effective.

From this point of view, this study stands as a first, fundamental step of a wider SML-risk management framework which looks at the same SML-risk as an opportunity to be seized to improve the quality of human life.

\footnotetext{
Acknowledgements

The work is framed within the activity of the ICL-IPL project No 248 on "Innovation in slow-moving landslide risk assessment of roads and urban sites by combining multi-sensor multisource monitoring data" and is part of the Project DTA.AD003.478 on "Tipizzazione di frane su area vasta e su singolo versante" of the CNR-Department of "Scienze del sistema Terra e Tecnologie per I'Ambiente". The used DInSAR data were provided by the Italian Ministry of the Environment and Protection of Land and Sea (MATTM) within the Italian Piano Straordinario di Telerilevamento Ambientale (PST-A) (CS2960/2017/603-0015584.25-07-2017).
}

\section{Authors' contributions}

Authors equally contributed to conceive and develop the research. All authors read and approved the final manuscript.

\section{Funding}

The work was partially funded by the Project of Relevant National Interest (PRIN) 2015 on "Innovative monitoring and design strategies for sustainable landslide risk mitigation" (ministerial code: 201572YTLA_007).

\section{Availability of data and materials}

Source data used in the paper will be available upon request.

\section{Declarations}

\section{Competing interests}

The authors declare that they have no competing interests.

\section{Author details}

${ }^{1}$ National Research Council of Italy (IRPI-CNR), Research Institute for GeoHydrological Protection, via Cavour 4/6, 87030 Cosenza, Italy. ${ }^{2}$ Department of Civil Engineering, University of Salerno, via Giovanni Paolo II, 132, 84084 Fisciano, Salerno, Italy.

Received: 27 July 2021 Accepted: 28 November 2021

Published online: 07 December 2021

\section{References}

Amodio-Morelli L, Bonardi G, Colonna V, Dietrich D, Giunta G, Ippolito F, Liguori V, Lorenzoni S, Paglionico A, Perrone V, Piccarreta G, Russo M, Scandone P, Zanettin-Lorenzoni E, Zuppetta A (1976) L'Arco Calabro Peloritano nell'Orogene Appenninico-Magrebide. Mem Soc Geol Ital 17:1-60

Antronico L, Borrelli L, Coscarelli R, Gullà G (2015) Time evolution of landslide damages to buildings: the case study of Lungro (Calabria, southern Italy). Bull Eng Geol Environ 74:47-59

Antronico L, Borrelli L, Coscarelli R, Pasqua A, Petrucci O, Gullà G (2013) Slope movements induced by rainfalls damaging an urban area: the Catanzaro case study (Calabria, southern Italy). Landslides 10:801-814

Bertini T, D’Elia B, Grisolia M, Olivero S, Rossi-Doria M (1984) Climatic conditions and slow movements of colluvium covers in central Italy. In: Proceedings of 4 th international symposium on landslides Toronto, vol 1, pp $367-376$

Bianchini S, Ciampalini A, Raspini F, Bardi F, Di Traglia F, Moretti S, Casagli N (2015) Multi-Temporal Evaluation of Landslide Movements and Impacts on buildings in San Fratello (Italy) by Means of C-Band and X-Band PSI Data. Pure Appl Geophys 172:3043-3065

Bianchini S, Cigna F, Del Ventisette C, Moretti S, Casagli N (2013) Monitoring landslide-induced displacements with TerraSAR-X persistent scatterer interferometry (PSI): Gimigliano case study in Calabria Region (Italy). Int J Geosci 2013(4):1467-1482

Biondino D, Borrelli L, Critelli S, Muto F, Gullà G (2018) The interplay of structural pathway and weathering intensity in forming mass-wasting processes in deeply weathered gneissic rocks (Sila Massif, Calabria, Italy). J Maps 14:242-256

Bonardi G, Cello G, Perrone V, Tortorici L, Turco E, Zuppetta A (1982) The evolution of the northern sector of the Calabria-Peloritani Arc in a semiquantitative palinspastic restoration. Bollettino Della Società Geologica Italiana 101:259-274

Bonì R, Bordoni M, Vivaldi V, Troisi C, Tararbra M, Lanteri L, Zucca F, Meisina C (2020) Assessment of the Sentinel-1 based ground motion data feasibility for large scale landslide monitoring. Landslides 17:2287-2299

Borrelli L, Antronico L, Gullà G, Sorriso-Valvo GM (2014) Geology, geomorphology and dynamics of the 15 February 2010 Maierato landslide (Calabria, Italy). Geomorphology 208:50-73

Borrelli L, Antronico L, Le Pera E, Pisano B, Sorriso-Valvo M (2021) Morphology, properties, and source of windblown sediments of the coastal dune field in the Gioia Tauro Plain, Calabria, southern Italy. CATENA 201:105193 
Borrelli L, Ciurleo M, Gullà G (2018a) Shallow landslide susceptibility assessment in granitic rocks using GIS-based statistical methods: the contribution of the weathering grade map. Landslides 15:1127-1142

Borrelli L, Critelli S, Gullà G, Muto F (2015) Weathering grade and geotectonics of the western-central Mucone River basin (Calabria, Italy). J Maps 11(4):606-624

Borrelli L, Greco R, Gullà G (2007) Weathering grade of rock masses as a predisposing factor to slope instabilities: reconnaissance and control procedures. Geomorphology 87(3):158-175

Borrelli L, Gullà G (2017) Tectonic constraints on a deep-seated rock slide in weathered crystalline rocks. Geomorphology 290(2017):288-316

Borrelli L, Nicodemo G, Ferlisi S, Peduto D, Di Nocera S, Gullà G (2018b) Geology, slow-moving landslides, and damages to buildings in the Verbicaro area (north-western Calabria region, southern Italy). J Maps 14(2):32-44

Brunetti M, Caloiero T, Coscarelli R, Gullà G, Nanni T, Simolo C (2012) Precipitation variability and change in the Calabria region (Italy) from a high resolution daily dataset. Int J Climatol 32(1):57-73

Burland JB, Broms BB, de Mello VFB (1977) Behaviour of foundations and structures. SOA Report. In: Proceedings of the 9th international conference on soil mechanics and foundation engineering, Tokyo, vol 2, pp 495-546

Calcaterra D, Parise M (2010) Weathering in the crystalline rocks of Calabria, Italy, and relationships to landslides. In: Calcaterra D, Parise M (eds) Weathering as predisposing factor to slope movements. Geological Society of London, Engineering Geology Series, Special Publication, vol 23, pp 105-130

Caloiero T, Buttafuoco G, Coscarelli R, Ferrari E (2015) Spatial and temporal characterization of climate at regional scale using homogeneous monthly precipitation and air temperature data: an application in Calabria (southern Italy). Hydrol Res 46(4):629-646

Caloiero T, Coscarelli R, Ferrari E, Mancini M (2011) Trend detection of annual and seasonal rainfall in Calabria (Southern Italy). Int J Climatol 31(1):44-56

Calvello M, Cascini L, Mastroianni S (2013) Landslide zoning over large areas from a sample inventory by means of scale-dependent terrain units. Geomorphology 182:33-48

Calvello M, Peduto D, Arena L (2017) Combined use of statistical and DInSAR data analyses to define the state of activity of slow-moving landslides. Landslides 14:473-489

Cascini L (2015) Geotechnics for urban planning and land use management. Italian Geotech J 49(4):7-62

Cascini L, Peduto D, Pisciotta G, Arena L, Ferlisi S, Fornaro G (2013) The combination of DInSAR and facility damage data for the updating of slow-moving landslide inventory maps at medium scale. Nat Hazards Earth Syst Sci 13:1527-1549

Casmez (1969) Carta Geologica della Calabria in scala 1:25,000 [Geological map of Calabria at 1:25,000 scale]. Poligrafica \& Cartevalori.

Catani F, Casagli N, Ermini L, Righini G, Menduni G (2005) Landslide hazard and riskmapping at catchment scale 2005 Arno River basin. Landslides 2:329-342

Cigna F, Bianchini S, Casagli N (2013) How to assess landslide activity and intensity with persistent scatterer interferometry (PSI): the PSI-based matrix approach. Landslides 10:267-283

Conforti M, Mercuri M, Borrelli L (2021) Morphological changes detection of a large earthflow using archived images, LiDAR-derived DTM, and UAVbased remote sensing. Remote Sensing 13(1):120. https://doi.org/10. 3390/rs13010120

Corominas J, van Westen C, Frattini P, Cascini L, Malet J-P, Fotopoulou S, Catani F, Van Den Eeckhaut M, Mavrouli O, Agliardi F, Pitilakis K, Winter MG, Pastor M, Ferlisi S, Tofani V, Hervàs J, Smith JT (2014) Recommendations for the quantitative analysis of landslide risk. Bull Eng Geol Environ 73(2):209-263

Coscarelli R, Caloiero T (2012) Analysis of daily and monthly rainfall concentration in Southern Italy (Calabria region). J Hydrol 416-417:145-156

Cruden DM, Varnes DJ (1996) Landslide types and processes. In: Turner AK, Schuster RL (eds) Landslides: investigation and mitigation. Transportation research board, US National Research Council, Washington DC, Special Report 247, Chapter 3, pp 36-75
Di Maio C, Vassallo R, Vallario M (2013) Palstic and viscous shear displacements of a deep and very slow landslide in stiff clay formation. Eng Geol 162:53-66

Donnini M, Napolitano E, Salvati P, Ardizzone F, Bucci F, Fiorucci F, Santangelo M, Cardinali M, Guzzetti F (2017) Impact of event landslides on road networks: a statistical analysis of two Italian case studies. Landslides 14:1521-1535

Fell R, Corominas J, Bonnard Ch, Cascini L, Leroi E, Savage W (2008) Guidelines for landslide susceptibility, hazard and risk zoning for land use planning. Eng Geol 102(3-4):85-98

Ferlisi S (2004) A simple mechanical model for the interpretation of translational active landslides involving detrital covers. In: Lacerda W, Ehrlich M, Fontoura SAB, Sayão ASF (eds) Landslides: evaluation and stabilization. Proceedings of the ninth international symposium on landslides, Rio de Janeiro (Brazil), 28 June-2 July 2004. CRC Press, Vol II, pp 1227-1232

Ferlisi S, Gullà G, Nicodemo G, Peduto D (2019) A multi-scale methodological approach for slow-moving landslide risk mitigation in urban areas, southern Italy. Euro-Mediterr J Enviro Integr 4(20):1-15

Ferlisi S, Marchese A, Peduto D (2021) Quantitative analysis of the risk to road networks exposed to slow-moving landslides: a case study in the Campania region (southern Italy). Landslides 18:303-319

Ferlisi S, Peduto D, Gullà G, Nicodemo G, Borrelli L, Fornaro G (2015) The use of DInSAR data for the analysis of building damage induced by slow-moving landslides. In: Lollino G, Giordan D, Crosta GB, J Corominas J, Azzam R, Wasowski J, Sciarra N (eds) Engineering geology for society and territory-landslide processes. vol 2. Springer, Berlin, pp 1835-1839. https:// doi.org/10.1007/978-3-319-09057-3_325

Fernández-Merodo JA, García-Davalillo JC, Herrera G, Mira P, Pastor M (2014) $2 \mathrm{D}$ viscoplastic finite element modelling of slow landslides: the Portalet case study (Spain). Landslides 11:29-42

Ferretti A, Prati C, Rocca F (2001) Permanent scatterers in SAR interferometry. IEEE Trans Geosci Remote Sens 39:8-20

Ghisetti F (1979) Evoluzione neotettonica dei principali sistemi di faglie della Calabria Centrale. Bollettino Della Società Geologica Italiana 98:387-430

Grana V, Tommmasi P (2014) A deep-seated slow movement controlled by structural setting in marly formations of Central Italy. Landslides 11:195-212

Gullà G (2014) Field monitoring in sample sites: hydrological response of slopes with reference to widespread landslide events. Procedia Earth Planet Sci 9:44-53

Gullà G, Aceto L, Antronico L, Borrelli L, Caloiero T, Capparelli G, Coscarelli R, Critelli S, Greco R, Maiorano SC, Muto F, Petrucci O, Pasqua AA, Perri F, Tripodi V, Versace P (2010) Applicazione delle metodologie proposte per la valutazione della pericolosità da frana alla scala del singolo versante. Report [RF04] POR Calabria 2000-2006-Misura 1.4 Sistemi Insediativi, CNR-IRPI, p 701 (in Italian)

Gullà G, Aceto L, Antronico L, Borrelli L, Coscarelli R, Perri F (2018a) A smart geotechnical model in emergency conditions: a case study of a medium deep landslide in Southern Italy. Eng Geol 234:138-152

Gullà G, Antronico L, Borrelli L, Caloiero T, Coscarelli R, lovine G, Nicoletti PG, Pasqua AA, Petrucci O, Terranova O (2009) Indicazioni conoscitive e metodologiche connesse all'evento di dissesto idrogeologico dell'autunno-inverno 2008-2009 in Calabria. Geol Calabria 10:4-21

Gullà G, Antronico L, laquinta P, Terranova O (2008) Susceptibility and triggering scenarios at a regional scale for shallow landslides. Geomorphology 99:39-58

Gullà G, Caloiero T, Coscarelli R, Petrucci O (2012) A proposal for a methodological approach to the characterization of Widespread Landslide events: an application to Southern Italy. Nat Hazards Earth Syst Sci 12:165-173

Gullà G, Peduto D, Borrelli L, Antronico L, Fornaro G (2017) Geometric and kinematic characterization of landslides affecting urban areas: the Lungro case study (Calabria, southern Italy). Landslides 14(1):171-188

Gullà G, Calcaterra S, Gambino P, Borrelli L, Muto F (2018b) Long-term measurements using an integrated monitoring network to identify homogeneous landslide sectors in a complex geo-environmental context (Lago, Calabria, Italy). Landslides. https://doi.org/10.1007/s10346-018-0974-4

Herrera G, Gutierrez F, Garcıa-Davalillo JC, Guerrero J, Notti D, Galve JP, Fernandez-Merodo JA, Cooksley G (2013) Multi-sensor advanced DInSAR 
monitoring of very slowlandslides: the Tena Valley case study (Central Spanish Pyrenees). Remote Sens Environ 128:31-43

Infante D, Di Martire D, Confurto P, Tessitore S, Tomas T, Calcaterra D, Ramondini M (2020) Assessment of building behavior in slow-moving landslide-affected areas through DInSAR data and structural analysis. Eng Struct 199:109638

Köppen W (1936) Das geographische system Der Klimate. In: Köppen W, Geiger R, Teil C (eds) Handbuch der Klimatologie, vol Vol. 5. Gebrüder Bornträger, Berlin, pp 1-46

Leroueil S (2001) Natural slopes and cuts: movement and failure mechanisms. Géotechnique 51(3):197-243

Maino A, Mele A, Calcaterra D, Di Martire D, Infante D, Prato A, Ramondini M (2021) The use of satellite data to support the structural health monitoring in areas affected by slow-moving landslides: a potential application to reinforced concrete buildings. Struct Health Monitor. https://doi.org/ 10.1177/2F1475921720983232

MATTM (2010) Piano Straordinario di Telerilevamento Ambientale. Website: http://www.pcn.minambiente.it/mattm/en/not-ordinary-plan-ofremote-sensing/. Accessed 20 July 2021

Mavrouli O, Corominas J, Ibarbia I, Nahikari Alonso N, loseba Jugo I, Ruiz J, Luzuriaga S, Navarro JA (2019) Integrated risk assessment due to slope instabilities in the roadway network of Gipuzkoa, Basque Country. Nat Hazards Earth Syst Sci 19(2):399-419

Monaco C, Tortorici L (2000) Active faulting in the Calabrian Arc and eastern Sicily. J Geodyn 29:407-424

Morelli S, Pazzi V, Tanteri L, Nocentini M, Lombardi L, Gigli G, Tofani V, Casagli N (2020) Characterization and geotechnical investigations of a riverbank failure in Florence, Italy, UNESCO World Heritage Site. J Geotech Geoenviron Eng 146(10):05020009

Nappo N, Peduto D, Mavrouli O, van Westen CJ, Gullà G (2019) Slow-moving landslides interacting with the road network: analysis of damage using ancillary data, in situ surveys and multi-source monitoring data. Eng Geol 260:105244. https://doi.org/10.1016/j.enggeo.2019.105244

Negulescu C, Ulrich A, Baills A, Seyedi DM (2014) Fragility curves for masonry structures submitted to permanent ground displacements and earthquakes. Nat Hazards 74(3):1461-1474

Nicodemo G, Ferlisi S, Peduto D, Aceto L, Gullà G (2020a) Damage to masonry buildings interacting with slow-moving landslides: a numerical analysis. In: Calvetti F et al (eds) Proceedings of the VII Italian conference of researchers in geotechnical engineering —CNRIG - Lecco, Italy 3-5 July 2019. Springer Nature Switzerland AG 2020, LNCE 40, pp 52-61. https:// doi.org/10.1007/978-3-030-21359-6_6

Nicodemo G, Peduto D, Ferlisi S (2020b). Building damage assessment and settlements monitoring in subsidence-affected urban area: case study in The Netherlands. In: Proceeding of IAHS. International Association of Hydrological Sciences, vol 382, pp 651-656. https://doi.org/10.5194/ piahs-382-651-2020

Nicodemo G, Peduto D, Ferlisi S, Gullà G, Borrelli L, Fornaro G, Reale D (2017b) Analysis of building vulnerability to slow-moving landslides via A-DInSAR and damage survey data. In: Mikoš M, Tiwari B, Yin Y, Sassa K (eds) Advancing culture of living with landslides-Proceedings of the 4th World Landslide Forum, Ljubljana, Slovenia, May 29-June 02, 2017. Springer International Publishing Switzerland, vol 2, pp 889-907. ISBN: 978-3-319-53497-8

Nicodemo G, Peduto D, Ferlisi S, Gullà G, Reale D, Fornaro G (2018) DInSAR data integration in vulnerability analysis of buildings exposed to slowmoving landslides. In: Proceedings of IEEE international geoscience and remote sensing symposium (IGARSS 2018), Valentia (Spain), 22-27 July 2018, pp 6111-6114. https://doi.org/10.1109/IGARSS.2018.8518808

Nicodemo G, Peduto D, Ferlisi S, Maccabiani J (2017a) Investigating building settlements via very high resolution SAR sensors. In: Proceedings of the 5th international symposium on life-cycle civil engineering, IALCCEDelft, The Netherlands 16-19 October 2016. CRC/Press Balkema, pp 2256-2263

Noviello C, Verde S, Zamparelli V, Fornaro G, Pauciullo A, Reale D, Nicodemo G, Ferlisi S, Gullà G, Peduto D (2020) Monitoring buildings at landslide risk with SAR: a methodology based on the use of multipass interferometric data. IEEE Geosci Remote Sens Mag 8(1):91-119

Open data/Geoportal Calabria region (2016) Website: http://geoportale.regio ne.calabria.it/opendata. Accessed 20 July 2021
PAI 2016 (Hydrogeological Asset Plan released in 2016) Website: https://www. distrettoappenninomeridionale.it/index.php/elaborati-di-piano-menu/ ex-adb-calabria-menu/piano-stralcio-assetto-idrogeologico-rischio-dafrana-articolo. Accessed 20 July 2021

Peduto D, Cascini L, Arena L, Ferlisi S, Fornaro G, Reale D (2015) A general framework and related procedures for multiscale analyses of DInSAR data in subsiding urban areas. ISPRS J Photogramm Remote Sens 105:186-210

Peduto D, Ferlisi S, Nicodemo G, Reale D, Pisciotta G, Gullà G (2017) Empirical fragility and vulnerability curves for buildings exposed to slow-moving landslides at medium and large scales. Landslides 14(6):1993-2007

Peduto D, Korff M, Nicodemo G, Marchese A, Ferlisi S (2019a) Empirical fragility curves for settlement-affected buildings: analysis of different intensity parameters for seven hundred masonry buildings in The Netherlands. Soils Found 59(2):380-397

Peduto D, Nicodemo G, Caraffa M, Gullà G (2018) Quantitative analysis of consequences to masonry buildings interacting with slow-moving landslide mechanisms: a case study. Landslides 15(10):2017-2030

Peduto D, Nicodemo G, Cuevas-Gonzáles M, Crosetto M (2019b) Analysis of damage to buildings in urban centres on unstable slopes via TerraSARX PSI data: the case study of El Papiol town (Spain). IEEE Geosci Remote Sens Lett 16(11):1706-1710. https://doi.org/10.1109/LGRS.2019.29075 57

Peduto D, Nicodemo G, Nappo N, Gullà G (2021a) Innovation in analysis and forecasting of vulnerability to slow-moving landslides. Innovation in Analysis and Forecasting of Vulnerability to Slow-Moving Landslides. In: Guzzetti F, Mihalić Arbanas S, Reichenbach P, Sassa K, Bobrowsky PT, Takara K (eds) Understanding and reducing landslide disaster risk-WLF 2020. ICL contribution to landslide disaster risk reduction. Springer, Cham, pp 441-446. https://doi.org/10.1007/978-3-030-60227-7_51

Peduto D, Oricchio L, Nicodemo G, Crosetto M, Ripoll J, Buxó P, Janeras M (2021b) Investigating the kinematic features of an unstable urban slope and the effects on the exposed facilities by merging conventional and GBSAR monitoring data: case of Barberà de la Conca (Catalonia, Spain). Landslides 1:13. https://doi.org/10.1007/s10346-020-01500-9

Peduto D, Pisciotta G, Nicodemo G, Arena L, Ferlisi S, Gullà G, Borrelli L, Fornaro $G$, Reale D (2016) A procedure for the analysis of building vulnerability to slow-moving landslides. In: Daponte P, Simonelli AL (eds). Proceedings of the 1st IMEKO TC4 international workshop on metrology for geotechnics-Benevento, Italy, March 17-18, 2016, pp 248-254. ISBN: 978-92-990075-0-1

Peduto D, Santoro M, Aceto L, Borrelli L, Gullà G (2021c) Full integration of geomorphological, geotechnical, A-DInSAR and damage data for detailed geometric-kinematic features of a slow-moving landslide in urban area. Landslides 18(3):807-825

Picarelli L, Urciuoli G, Russo C (2004) Effect of groundwater regime on the behaviour of clayey slopes. Can Geotech J 41:467-484

Raspini F, Bianchini S, Ciampalini A, Del Soldato M, Montalti R, Solari L, Tofani V, Casagli N (2019) Persistent Scatterers continuous streaming for landslide monitoring and mapping: the case of the Tuscany region (Italy). Landslides 16(10):2033-2044

Refice A, Spalluto L, Bovenga F, Fiore A, Miccoli MN, Muzzicato P, Nitti DO, Nutricato R, Pasquariello G (2019) Integration of persistent scatterer interferometry and ground data for landslide monitoring: the Pianello landslide (Bovino, Southern Italy). Landslides 16:447-468

Scarciglia F, Critelli S, Borrelli L, Coniglio S, Muto F, Perri F (2016) Weathering profiles in granitoid rocks of the Sila Massif uplands, Calabria, southern Italy: New insights into their formation processes and rates. Sed Geol 336:46-67

Scarciglia F, Le Pera E, Vecchio G, Critelli S (2005) The interplay of geomorphic processes and soil development in an upland environment, Calabria, South Italy. Geomorphology 69:169-190

Solari L, Del Soldato M, Montaltia R, Bianchini S, Raspini F, Thuegaz F, Bertolo D, Tofani V, Casagli N (2019) A Sentinel-1 based hot-spot analysis: landslide mapping in north-western Italy. Int J Remo Sens Int J Remote Sens 40(20):7898-7921

Sorriso-Valvo M (1993) The geomorphology of Calabria, a sketch. Geogr Fis Din Quat 16:75-80

Sorriso-Valvo M, Tansi C (1996) Grandi frane e deformazioni gravitative profonde diversante della Calabria. Note illustrative per la carta al 250000. Geogr Fis Din Quat 19:395-408 (in Italian) 
Sorriso-Valvo M, Antronico L, Gaudio R, Gullà G, lovine G, Merenda L, Minervino I, Nicoletti PG, Petrucci O, Terranova O (2004) Carta dei dissesti causati in Calabria meridionale dall'evento meteorologico dell'8-10 settembre 2000. CNR-GNDCI Pubblication, Vol 2859. Rubbettino Publisher, Soveria Mannelli, Italy

Terranova OG, laquinta P (2011) Temporal properties of rainfall events in Calabria (southern Italy). Nat Hazard Earth Sys 11:751-757

Tortorici L (1982) Lineamenti Geologico-Strutturali Dell'arco Calabro- Peloritano. Rend Soc Geol It Miner Petrol 38(3):927-940 (in Italian)

Tortorici L, Monaco C, Tansi C, Cocina O (1995) Recent and active tectonics in the Calabrian Arc (southern Italy). Tectonophysics 243:37-55

Tripodi V, Muto F, Brutto F, Perri F, Critelli S (2018) Neogene-Quaternary evolution of the forearc and backarc regions between the Serre and Aspromonte Massifs, Calabria (southern Italy). Mar Pet Geol 95:328-343

Uzielli M, Catani F, Tofani V, Casagli N (2015) Risk analysis for the Ancona landslide — I: characterization of landslide kinematics. Landslides 12(1):69-82

Van Dijk JP, Bello M, Brancaleoni GP, Cantarella G, Costa V, Frixa A, Golfetto F, Merlini S, Riva M, Torricelli S, Toscano C, Zerilli A (2000) A regional structural model for the northern sector of the Calabrian Arc (southern Italy). Tectonophysics 324:267-320

van Westen CJ, van Asch TWJ, Soeters R (2006) Landslide hazard and risk zonation: why is it still so difficult? Bull Eng Geol Environ IAEG 65:167-184

Versace P, Ferrari E, Gabriele S, Rossi F (1989) Flood evaluation in Calabria. CNRGNDCl, Publ. 987, CNR IRPI, Cosenza

Vitale G (2017) Analisi del danno di edifici ricadenti in aree in frana: i casi studio di Gimigliano e San Mango d'Aquino. MSc Thesis, University of Salerno (in Italian)

Wasowski J (2006) Investigating landslides with spaceborne SyntheticAperture Radar (SAR) interferometry. Eng Geol 88:173-199

Wasowski J, Bovenga F (2014) Investigating landslides and unstable slopes with satellite multi temporal interferometry: current issues and future perspectives. Eng Geol 174:103-138

Westaway R (1993) Quaternary uplift of Southern Italy. J Geophys Res 98:21741-22177

\section{Publisher's Note}

Springer Nature remains neutral with regard to jurisdictional claims in published maps and institutional affiliations.

\section{Submit your manuscript to a SpringerOpen ${ }^{\odot}$ journal and benefit from:}

- Convenient online submission

- Rigorous peer review

- Open access: articles freely available online

- High visibility within the field

- Retaining the copyright to your article

Submit your next manuscript at $\gg$ springeropen.com 